University of Nebraska - Lincoln

DigitalCommons@University of Nebraska - Lincoln

Agronomy \& Horticulture -- Faculty Publications

Agronomy and Horticulture Department

$1-1948$

\title{
Changes in Vegetation and Production of Forage Resulting from Grazing Lowland Prairie
}

J. E. Weaver

University of Nebraska-Lincoln

R. W. Darland

University of Nebraska-Lincoln

Follow this and additional works at: https://digitalcommons.unl.edu/agronomyfacpub

Part of the Plant Sciences Commons

Weaver, J. E. and Darland, R. W., "Changes in Vegetation and Production of Forage Resulting from Grazing Lowland Prairie" (1948). Agronomy \& Horticulture -- Faculty Publications. 485.

https://digitalcommons.unl.edu/agronomyfacpub/485

This Article is brought to you for free and open access by the Agronomy and Horticulture Department at DigitalCommons@University of Nebraska - Lincoln. It has been accepted for inclusion in Agronomy \& Horticulture -Faculty Publications by an authorized administrator of DigitalCommons@University of Nebraska - Lincoln. 


\title{
ECOLOGY
}

VoL. 29

JANUARY, 1948

No. 1

\section{CHANGES IN VEGETATION AND PRODUCTION OF FORAGE RESULTING FROM GRAZING LOWLAND PRAIRIE *}

\author{
J. E. Weaver and R. W. Darland
}

\section{INTRODUCTION}

When the early settlers came to Iowa, Nebraska, and adjacent territory they entered an almost boundless sea of grass. Throughout the years the prairie has been largely broken for crop production, but even today there still remain considerable tracts of native grassland annually mowed for hay and far greater ones of native pasture (Weaver and Fitzpatrick, '34). Climax grassland when grazed lightly or moderately may retain essentially its natural composition over extremely long periods. It is only when grazing animals are circumscribed in their range by fences and when too large a population is thus confined for too long a time that grazing and trampling become so excessive that the normal cover cannot be mainitained. The prairie degenerates. The best-liked and most nutritious grasses and forbs wane and disappear. They are replaced by species of lower grazing value. Weeds become abundant. The farmer or rancher says the prairie has been "grazed out." Often the land is plowed and thus another tract of prairie forever disappears. Although extensive researches have been made upon degeneration of upland prairie under excessive pasturing, it is believed that similar studies of the break-down of postclimax prairie on lowland have not been recorded (Weaver and Hansen, '41, '41a). The area of this research lies in

* Contribution from the Department of Botany, University of Nebraska, No. 151. The investigation was aided by a grant from the Research Council of the University of Nebraska. the west-central portion of the great body of grassland, now largely broken, known as true or mid-grass prairie.

Native prairie has been the home of grazing animals for untold centuries. Prairie plants are eminently adapted to grazing, and conservative grazing is little or no more harmful to native pastures than is total protection. But to maintain production, moderate grazing must be practiced. The task of maintaining grazing lands in a high state of productivity is fundamentally based upon a knowledge of the growth requirements of native vegetation; in fact, a knowledge of native plants and forage conditions is vital to the successful management of pasture or range. Hence, in this study major attention has been given to the changes in the vegetation resulting from the seasonal grazing patterns of the cattle and how these were affected by environment. The research has been supplemented by ascertaining the kinds and amounts of forage production month by month and year by year from ' 43 to ' 46 , inclusive. The forage use or consumption has also been similarly correlated with both environment and degeneration of the grassland.

\section{Location, Topography, and Soll}

The pasture occupies a level tract of approximately 50 acres about 3 miles northeast of Havelock, a suburb of Lincoln, Nebraska. It lies just east of the junction of Stevens Creek, which bounds it on the south and west, and Salt Creek. The land is nearly level, but well drained, 
and only a few widely scattered low spots were indicated by the presence of slough grass (Spartina pectinata). ${ }^{1}$ A shallow ravine with rounded sides extended entirely across it but this was covered mostly with Kentucky bluegrass (Poa pratensis) sod. The soil is Wabash silt loam, very dark in color, porous, and highly productive. In it the roots of big bluestem (Andropogon furcatus) and western wheat grass (Agropyron smithii) extended in thick masses to depths of 6 to 7 feet, and even the more shallowly rooted bluegrass penetrated to 3.5 feet.

\section{Methods of Study}

Examination of conditions in the entire pasture was made each month from April to October, inclusive. The findings, as well as notes on observations made at almost weekly intervals, were recorded for study. Emphasis was placed on the development of the individual species and especially the degree to which they were grazed and their response to grazing. Strong, portable exclosures, each enclosing 29 square feet, were used. Each consisted of a frame of four steel posts 7 feet in length bolted together at the top but spread at the base where they were bolted to wooden strips $2 \times 2$ inches in width and 5.5 feet long. The ends of the posts extended beyond the strips about 2 inches. The frame was covered with a heavy grade of woven fencing wire from the bottom to a height of 5 or 6 feet. The purpose of the exclosures, which were moved to a new location each month, was to determine, by clipping, the monthly yield and consumption. Method of operating the exclosures will be explained with the study of consumption of forage and yield. Only brief reference to them is made in connection with the seasonal grazing patterns and degeneration.

The value of exclosures in presenting at the end of each month sample areas of

1 Scientific names of grasses are according to Hitchcock's Manual of the Grasses of the United States; those of other plants, Britton and Brown's illustrated Flora. vegetation ungrazed during that interval was very great. They revealed the relative height-growth of each species after a month of protection and the rate of recovery after grazing. The vigor of the grasses was also shown. Each species exemplified by its development or lack of growth what it could produce if left undisturbed. Here one could plainly see how the number of stems within the bunches or sods was being reduced. When the new tops were present, this thinning of the stand showed plainly, but poorly if at all outside the exclosure where grazing was close. By study of the protected vegetation one could see clearly what the cattle must have eaten in the adjacent area. This included small amounts of sedges, grasses, and forbs of species found only with difficulty in closely grazed pasture. Many relicts were observed only in the exclosures. Exclosures emphasized the removal of flower stalks of bluegrass or other grasses which might have passed unnoticed except for their presence here. Likewise they revealed the removal of certain weeds, as horseweed (Leptilon canadense), sometimes grazed so closely with the grasses that the remaining parts

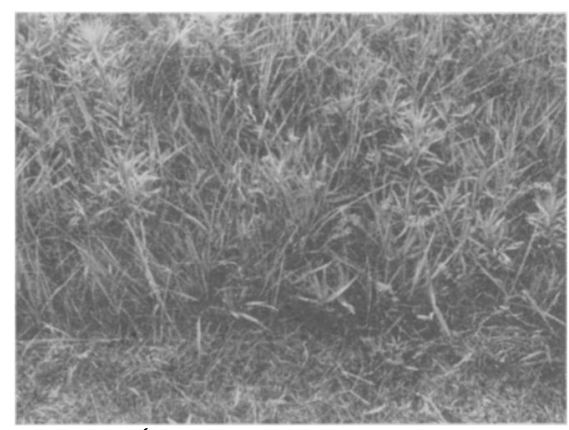

FIg. 1. Detail of a portion of the vegetation in bluegrass sod on August 1, '45. It had been protected from grazing during July. Note close grazing in foreground outside the exclosure, which has been removed. The bulk of the vegetation (Kentucky bluegrass, Poa pratensis) is 3-4 inches tall. Scattered plants of big bluestem (Andropogon furcatus) are 7-9 inches high. The bushy-topped forbs are horseweed (Leptilon canadense). All vegetation had been closely grazed in the surrounding area. 
were difficult to find (fig. 1). Permanent exclosures, which were also employed the last year of study, showed to what degree various species had been permanently weakened-whether their growth was late and slow or prompt, vigorous, and productive of flower stalks and seed. It also showed strikingly the effects of coarse weeds, as ironweed (Vernonia baldwinii), and those of untrampled lesser ones, as brome grasses and little barley (Hordeum pusillum), in shading or otherwise competing with prairie plants.

\section{VEGETATION}

The original vegetation was bluestem prairie with relict patches of slough grass and switchgrass (Panicum virgatum). Patches of buckbrush (Symphoricarpos occidentalis) also occurred but these were not extensive. But during the great drought, which began in '34, the grasses were considerably damaged by desiccation and by burial under deposits of windblown dust from surrounding cultivated fields. This resulted in changes in the composition of the vegetation. As a result of the disturbances following '34, this meadow, which formerly had been mowed each fall for its large yield of excellent hay, was grazed regularly after '39. When the present study began, in the fall of ' 42 , the pasture was composed

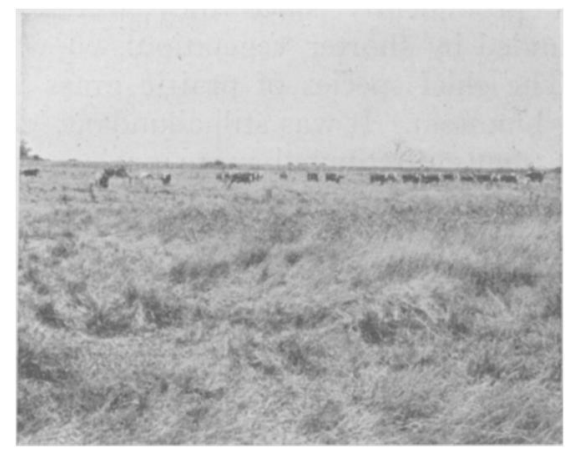

FIG. 2. View in the pasture on September 1, '44. The tall, light-colored grass on this side of the cattle and in the foreground is western wheat grass (Agropyron smithii) with a patch of buckbrush (Symphoricarpos occidentalis).

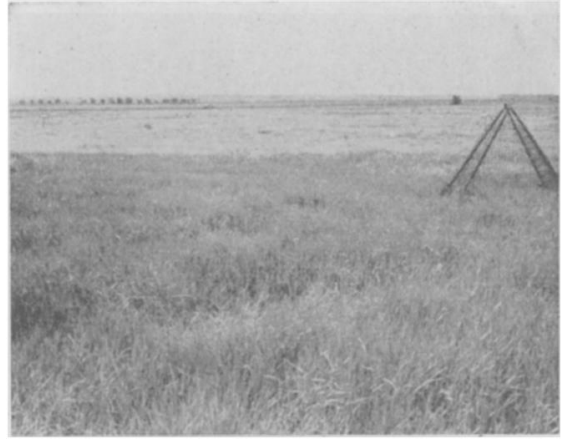

FIG. 3. View in the pasture looking southeast from an area of western wheat grass (dark) into the bluegrass type (light). An exclosure with a basal area of 29 square feet is shown in the foreground.

of three distinct types or communities of plants-western wheat grass, bluegrass, and prairie grasses, aside from weeds on the creek banks (figs. 2 and 3 ).

\section{Western wheat grass type}

Invasion and increase of western wheat grass ${ }^{2}$ were a direct result of the dry soil and high winds. Large amounts of wind-borne dust were deposited, often in layers an inch or less in depth but sometimes in drifts two feet deep. Under the deeper deposits all vegetation was destroyed and wheat grass promptly covered the drifts and mounds or thick layers of dust wherever they occurred. Sometimes the cover of dust resulted in incomplete destruction of the predrought vegetation. Thus, the wheat grass type was usually pure, but in places it included as much as 15 per cent of the native vegetation which had not died or had recovered where covering by dust was less severe. Areas of wheat grass were scattered throughout, some extending over many square rods. Some were found where no noticeable dust deposits occurred. All were characterized by very definite and easily discernible boundaries. The wheat grass type was typically a one-species stand and always the one species was dominant (fig.

\footnotetext{
${ }^{2}$ Hereafter, for brevity, this species will be designated as wheat grass.
} 


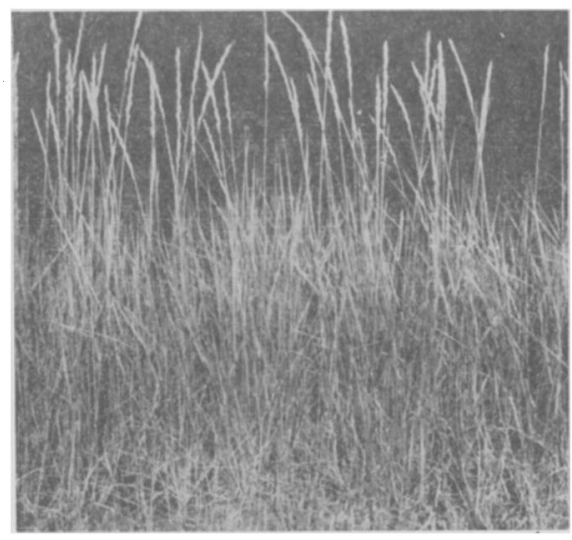

FIG. 4. Typical thick stand of well established western wheat grass. The height is about 3 feet.

4). Wheat grass is a coarse grass with numerous, rigid, vertical stems and abundant rhizomes. It begins growth very early in spring and several weeks before the bluestems and. most other prairie grasses renew their activities.

\section{Bluegrass type}

The bluegrass type was a community where somewhat more than half and often nearly all of the vegetation was composed of bluegrass. Since bluegrass was rarely found intermingling with wheat grass, origin of the type resulted from bluegrass more or less completely replacing the native prairie grasses. When first observed in ' 42 bluegrass had replaced much of the big bluestem in the ravine, and had also spread laterally over the level land as grazing progressed. Over about five acres near the junction of the creeks, on soil that had once been plowed and then abandoned, this type also occurred. Horseweed, summer-cypress (Kochia scoparia), hemp (Cannabis sativa), and other weeds which had formerly occupied the area thus bared began to give way to bluegrass in ' 43 and this grass took almost complete possession the next year.

The area covered by bluegrass in ' 42 ' 43 was difficult to determine. The southern portion, perhaps two-fifths of the en- tire pasture, still had considerable soif covered with tall weeds, as horseweed and lamb's quarters (Chenopodium album), and with ungrazed stands of wheat grass. A careful estimate assigned twofifths of the land to wheat grass and weeds, two-fifths to native prairie, and the remaining fifth to bluegrass. But by '44 the weeds were of little significance. The patches and larger areas of wheat grass were much more clearly defined. Much of the former weedy land had been claimed by bluegrass. Heavy grazing kept much of the bluegrass (and prairie relicts occurring in it) in the condition of a lawn. A basal cover of 75 to 84 per cent was found in well established stands. Surveys in ' 44 showed that wheat grass occupied one-third, native prairie about one-third, and bluegrass and weedy areas the remainder.

\section{Prairie type}

Drought and several years of grazing had considerably modified this lowland prairie. In ' 42 , slough grass occurred in a portion of the shallow ravine but this area was shared by an equal mixture of switchgrass. A few small, isolated patches of pure slough grass did occur elsewhere in slight depressions, but, like the former. they often possessed a dense undergrowth of bluegrass. Neither of the tall grasses was grazed below 2 to 3 feet; they stood out prominently since they were surrounded by shorter vegetation.

The chief species of prairie grass was big bluestem. It was still abundant. Relict stems distributed more or less over the entire area revealed its former wide distribution. Little bluestem (Andropogon scoparius) had also been widely scattered and could be found as bunches in various stages of degeneration even where bluegrass had formed a dense sod (fig. 5). Tall dropseed (Sporobolus asper), a coarse bunch grass of low preference for grazing, had increased during the years of drought. It sometimes occurred in small open patches but more usually as large isolated bunches. Since the bunches 


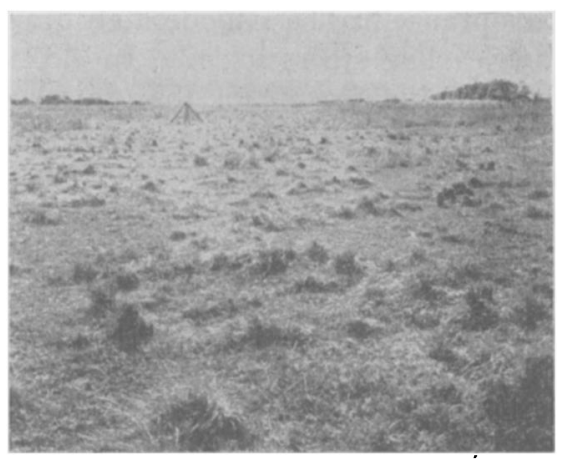

FIG. 5. An early stage in the reduction of native prairie to bluegrass. It illustrates close fall grazing of the bluestems (Andropogons) and other grasses, and of the invading bluegrass in September of ' 43 . The half-grazed bunches are mostly tall dropseed (Sporobolus asper) and little bluestem (Andropogon scoparius), but various other bunch grasses also occur.

were usually only slightly grazed they furnished a measure of protection to the more palatable grasses. Needle grass (Stipa spartea) was widely scattered throughout the relict prairie type and isolated bunches or clumps remained for a long time in bluegrass sod. This droughtenduring species had benefited by the open cover. Considerable seed was produced each year, except the last, and seedlings were abundant where the ground was more or less bare locally.

Scribner's panic grass (Panicum scribnerianum) increased greatly because of the open ground resulting from drought and deposit of dust. It occurred very abundantly in the prairie type but also in stands of bluegrass that were still open. In many drought-bared places it formed 50 to 80 per cent of the foliage cover. Penn sedge (Carex pennsylvanica) increased following the drought and was so abundant that it furnished considerable forage.

Blue grama (Bouteloua gracilis) was represented locally by several small patches; the largest covered only a few square rods. Side-oats grama (Bouteloua curtipendula) was common locally but too small in total amount to furnish much forage. Sand dropseed (Sporobolus cryptandrus), an invader from the mixed prairie westward, is well adapted to grow in dust-covered or loose, warm soil. It occurred in small patches in many places, sometimes being the only perennial grass. June grass (Koeleria cristata) was common but nowhere abundant. Prairie dropseed (Sporobolus heterolepis), also a bunch grass, was a common constituent of the prairie vegetation but one of only moderate abundance. Thus, the relict prairie type was composed of a relatively large number of both mid and tall grasses and a few short grasses. Wheat grass was not a component. Bluegrass formed an understory almost throughout with a 1 to 5 per cent stand which locally increased to 10 to 30 per cent. The transition to the bluegrass type resulted from repeated close grazing retarding the growth of the bunch grasses and big bluestem, as well as the aggressive habit of bluegrass in forming a dense continuous sod. In midsummer of ' 43 , the chief grasses, aside from invading bluegrass but including a sedge, were as follows in order of their abundance: big bluestem, needle grass, tall dropseed, Scribner's panic grass, penn sedge, little bluestem, and prairie dropseed.

No native forbs are especial components of bluegrass and wheat grass pastures. These grasses are both invaders and severe competitors of other species. The better they are developed the purer the stand. But this is not true of native prairie. It possesses a very large number of legumes, composites, and other forbs, mostly of high forage value. Many decrease under grazing-those for which the livestock have the greater preference; others, mostly uneaten, increase. Thus, the condition of any native pasture may be determined by examining (1) the prairie grasses that decrease under grazing (practically all of those mentioned in this type), (2) the forbs that decrease under grazing, (3) the grasses that increase under grazing (bluegrass, sideoats grama, etc.), and (4) the forbs that 
increase under grazing; that is, they become native weeds. If the pasture is badly overgrazed a group of invading species enters as (5) introduced weedy grasses and weedy forbs. These groups of species are listed and their habits described elsewhere (Weaver and Hansen, '41).

The abundance of native grasses and a large variety of highly palatable native forbs showed at once that this was a high-grade prairie. Had the livestock been removed for a year or two, the prairie type would have been indistinguishable from other native lowland prairies of eastern Nebraska. Entrance of wheat grass was clearly the effect of drought and dust. But the presence of the large proportion of bluegrass which spread rapidly every year to form the local bluegrass type at the expense of the native species, indicated too heavy stocking. Because of decrease due to drought and grazing no native forbs occurred here in such abundance as to furnish much forage or, except for ironweed, to constitute an important weed. Hence, a list of forbs and very minor grasses would be of little value. This prairie was typically representative of many others and will serve to show the general sequence of degeneration which has occurred over many hundreds of square miles of lowland prairie.

\section{Seasonal Grazing Patterns and Degeneration}

When one examines a native pasture week by week and ascertains the kinds of forage the cattle are consuming, a seasonal pattern of their grazing habits is to be found. This varies with the type of vegetation available to the livestock and its period of development and consequently varying palatability. It also varies with the type of grazing animal, whether young or mature, and especially the grazing pressure, which is often modified from year to year by variations in the number of livestock and in precipitation and temperature.
This prairie had been moderately grazed by 38 yearling steers in ' 42 . In ' 43 , the fourth grazing season for this grassland, 45 yearling steers and one mature cow were placed in the pasture on April 22 where they remained for approximately six months, until late in October. The owner of the land and the cattle, who weighed the steers in spring and late fall, found the weight in April varied between 400 and 450 pounds per animal, and the weight in October between 650 and 700 pounds. Since it is usual to consider a yearling steer 65 per cent of an animal unit, there were approximately 30 animal units in this 50 -acre tract. Since the grazing season extended over 6 months this was approximately 180 animal months of grazing. Such a heavy rate of stocking is possible for a few years on rich lowland soil but sooner or later the number of animals must be reduced because of depletion of forage.

\section{Environment and grazing in' 43}

Spring was cool and late. Soil was moist in spring and later wet by heavy rains to a depth of several feet. A1though there was mild drought in August, it was an excellent summer for growth; the accumulated moisture reserves of ' 42 promoted good yields.

Grazing in May was chiefly of weedy annual grasses, penn sedge, young bluegrass, and wheat grass. The patches of little barley and downy brome (Bromus tectorum), like those of penn sedge, were grazed wherever they occurred and furnished much forage. Relatively small amounts of bluegrass and wheat grass were consumed.

Throughout June bluegrass grew well and more of it was consumed but the most grazing was that of prairie grasses and wheat grass. The rapidly growing wheat grass occurred well above the old debris and was still relatively tender. It was grazed in quantity but only above 10-12 inches in height.

In July wheat grass was grazed scarcely at all. Owing to moist weather, blue- 
grass grew vigorously, but it was usually removed only from areas previously grazed. Here the new foliage was consumed in larger amounts than previously and grazing was closer than in June. Prairie grasses recovered rapidly after grazing and furnished the largest amounts of nutritious and palatable forage.

Drought in August retarded development of the grasses. The new growth of bluegrass was grazed to $0.5-1.5$ inches and mature bluegrass was also eaten. The cattle grazed a great deal of the old forage in relict prairie. They also consumed large quantities of summer-cypress, reducing the plants to a height of 4-6 inches. Despite an apparent search for forage, there was practically no grazing of wheat grass.

Rains in late August and early September, together with cooler weather, resulted in renewal of growth. But green forage was not abundant. Bluegrass was grazed very closely ( 0.5 inch) and more uniformly than before, and even to 3 inches in the roughs. ${ }^{3}$ But total amount

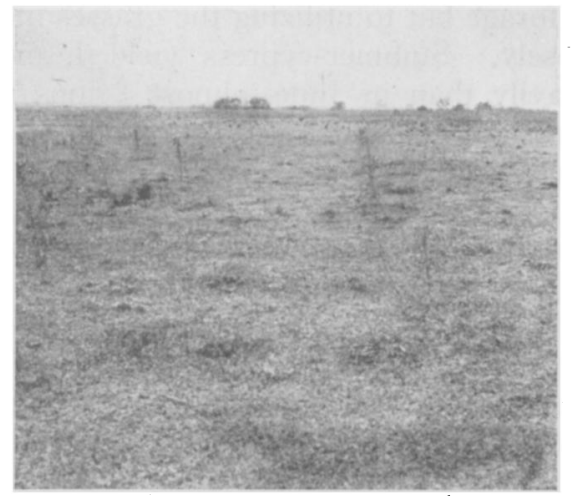

FIG. 6. Closely grazed bluegrass and remaining prairie grass in October, '43, when other green forage had become far less abundant than formerly. Isolated bunches of prairie grasses, except in distant background, and bluegrass roughs had practically disappeared.

3 Places in the pasture where the forage had not been removed for a year or more either because of the presence of weeds, dung, an abundance of less palatable species, or for other reasons, gave the vegetation a very irregular and uneven appearance. These have been des-

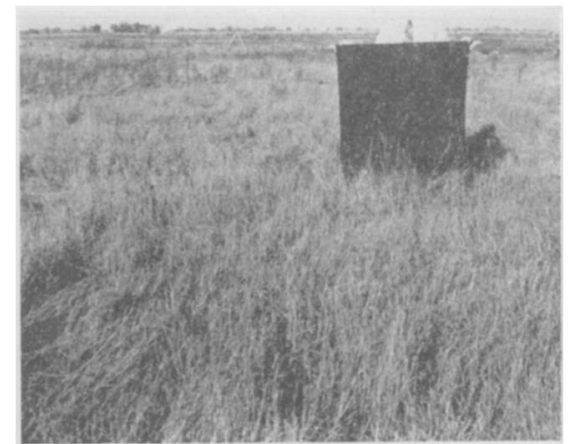

FIG. 7. Condition of wheat grass in midOctober, '43. Fall grazing had reduced it to a general height of 11 inches, but it had been grazed irregularly and in places flower stalks over 2 feet tall remained.

of forage from bluegrass was not great. So much of the half-dry prairie grass was eaten that prairie roughs in the bluegrass type all but disappeared (fig. 6). Summer-cypress and other edible weeds had dried. The shortage of forage combined with the new growth of wheat grass resulted in the consumption of a large amount of this species, except where the plants had lodged. About two-thirds of the dry forage was removed in obtaining the one-third that was green. In many places this grass was reduced to a height of 10 inches (fig. 7).

\section{Environment and grazing in '44}

Spring was cool, moist, and fully two weeks later than normal. June was a cool month with high rainfall (fig. 8). The summer was warm but with average weekly temperatures mostly less than $80^{\circ}$ F. Soil moisture was plentiful except for a dry period in August. Late fall was also dry. The year was unusually favorable for the growth of grasses. Thirty-eight yearling steers were placed in the pasture late in April. This number was increased by the addition of 5 cows on June 15. These 30 -animal units

ignated as roughs. Sometimes they occupied only a few square feet, areas of a few square yards were perhaps more common, but often they were larger. 


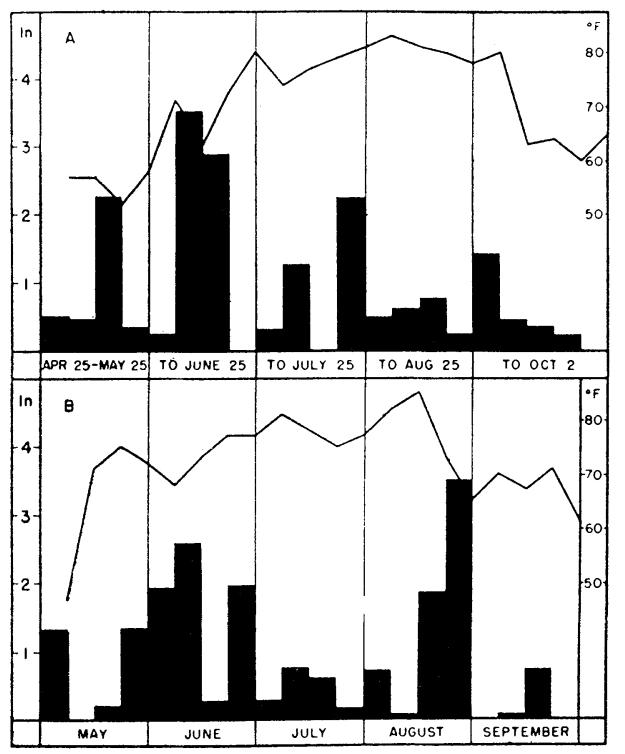

FIc. 8. Total rainfall in inches (approximately) by weeks, shown by the solid columns, and average weekly temperatures in degrees Fahrenheit, during the grazing seasons (A) of '43 and (B) ' 44.

constituted the herd throughout the grazing season. This was 172 animal months of grazing.

Spring grazing was mostly in wheat grass. Prairie grasses in early stages of growth, weedy winter annuals, and the short new growth of bluegrass furnished the remainder of the forage. The bluestems were just appearing above ground on May 1. But the early-growing needle grass, other cool-season grasses, and penn sedge were being grazed. Production of forage was low. Little barley where it grew thickly produced greater yields than a similar area of prairie. It and the annual bromes furnished much supplementary green feed. Because of close grazing the preceding season and the late spring, bluegrass furnished only a small amount of forage. Leaves of the new shoots of wheat grass were 6-10 inches high. Grazing occurred where the wheat grass had been eaten the previous year and also where the old stems had lodged close to the soil or had been flattened in bedding grounds and the new shoots grew above the debris. More forage was removed from the wheat grass type than from prairie grass and bluegrass combined.

In June grazing had definitely shifted away from wheat grass, since the plants matured. rapidly, and from little barley which had dried. Summer-cypress in the disturbed places along stream banks furnished considerable supplementary forage at the rate of about 1.5 tons per acre per month. During this warm month of favorable moisture relations, grazing in bluegrass was so general that large amounts of forage were removed from remaining roughs. But much more grazing occurred in the prairie type since here grew the best-liked grasses.

Wheat grass was not eaten during July. Production of bluegrass remained high because of plentiful soil moisture and moderate temperatures. Grazing in previously grazed places became closer but little forage was removed from roughs. Heavy grazing also occurred in the prairie type; here consumption was highest. This was not due to greater abundance of forage but to utilizing the grasses more closely. Summer-cypress yielded, more heavily than in June, almost 2 tons per acre. These much-relished plants were green and succulent.

Drought beginning late in July was coupled with high temperatures the first half of August (fig. 8). But ample rain fell and cooler weather prevailed the third and fourth weeks. Grazing during August became closer and more uniform. There was little evidence of grazing in the drying wheat grass. After the current yield of prairie grasses and bluegrass was consumed, the remaining forage necessary to satisfy the herd was taken largely from the roughs. Production of summercypress fell to about half that in July but the cattle kept it closely grazed.

Although production of prairie grasses was maintained during September, yield of bluegrass was greatly decreased. Grazing in both types was closer than in $\mathrm{Au}$ gust; all roughs were grazed. New 
growth of wheat grass began early in September and the shoots were soon $4-8$ inches tall. In grazing the new wheat grass and intermixed winter annuals, much dried forage was eaten. Total consumption was highest in this type. Considerable amounts of summer-cypress were still consumed.

Grazing was continued during the dry month of October.' Bluegrass and bluestems made practically no growth. Bluegrass under the buckbrush was grazed as were also both bluegrass and prairie roughs. The cattle subsisted almost entirely upon dry forage, of which wheat grass was least preferred.

\section{Environment and grazing in ' 45}

Spring was cold, wet, and very late. Cool, cloudy weather continued throughout June, a month with high rainfall, and vegetation flourished. There was just sufficient rain during July to keep the grasses green; temperatures were moderate. Drying soil in late July was mois-

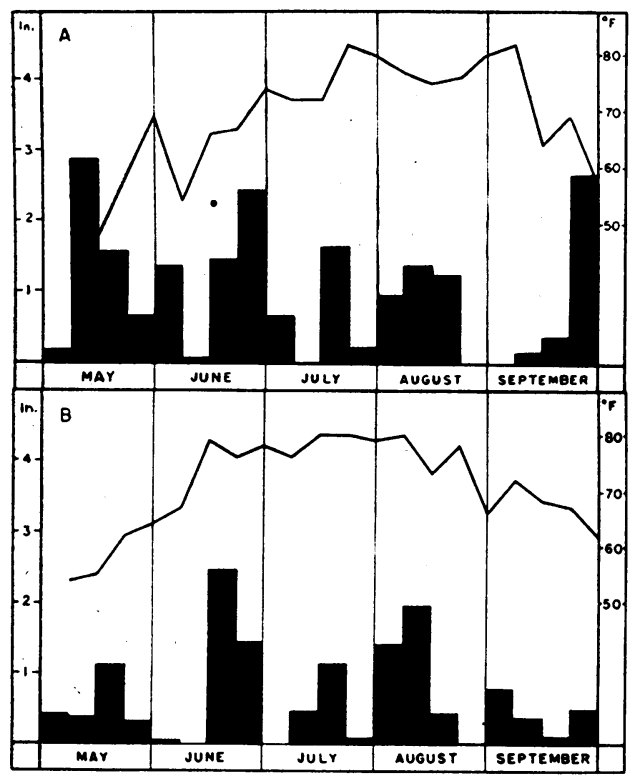

FIG. 9. Total rainfall in inches (approximately) by weeks, shown by the solid columns, and average weekly temperatures in degrees Fahrenheit, during the grazing seasons (A) of '45 and (B) ' 46.

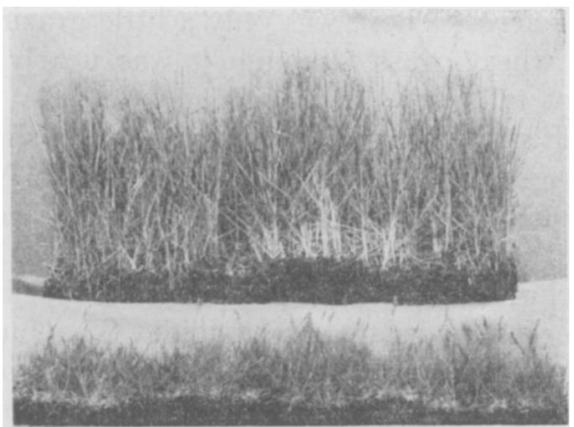

FIG. 10. Bluegrass sod (lower) from the pasture where it had been closely grazed for several years. (Upper) Bluegrass sod from a pasture where grazing in previous years had been moderate. The foliage heights are 1.5-2.5 and 9-10 inches, respectively, and that of flower stalks 3-5 and 12 inches. Photo. May 15, '45.

tened by rains in August, a month of moderately low temperatures. The season as a whole was favorable to grasses, except for prolonged drought from late August to late September (fig. 9). On May 1, 49 head of yearling steers, with an average weight of 347 pounds, were placed in the pasture. These 32 animal units were increased in mid-July to 35 . This amounted to approximately 202 animal months of grazing compared with 180 in '43.

Previous early grazing and trampling, followed by intensive grazing late in the fall, had completely destroyed the prairie type. Its territory was now occupied by bluegrass and relict prairie grasses. In areas grazed closely the preceding year bluegrass was only 1.5-2 inches tall (fig. 10). In places that had been fertilized it was not only greener but the height was 8-15 inches.

The cattle roamed widely over the pasture in May, selecting the conspicuously greener patches of bluegrass and grazing them back to 3-4 inches. Little barley and annual bromes often grew in thick stands, where they were grazed repeatedly. These grasses, 10-12 inches tall, produced large amounts of forage. In the subsere, little barley alone was consumed at the rate of nearly 2.5 tons 
per acre. There was only a little grazing of wheat grass although it was nearly a foot tall early in May.

Early in June there was a definite shift of grazing into the wheat grass. Although a third of this type was ungrazed and another third grazed only above 16 inches, yet consumption here was increased more than four-fold. The bulk of the forage this month was taken from wheat grass. Early in the month consumption of bluegrass was confined to irregular grazing of the places that had been repeatedly grazed in former years. The cattle were getting a good sprinkling of scattered relict bluestems with the bluegrass (fig. 11). Late in June grazing of bluegrass became general over much of the area. Consumption more than doubled. Winter annuals dried and their consumption in June was small; conversely, Scribner's panic grass grew well and was much grazed. It was consumed at the rate of $1,0.6$, and 0.56 ton per acre in June, July, and August, but decreased greatly in September. Even the coarse green stems of slough grass were grazed to a height of 4-8 inches.

By July flower stalks with woody stems and hard spikes had developed in wheat grass and storms had caused con-

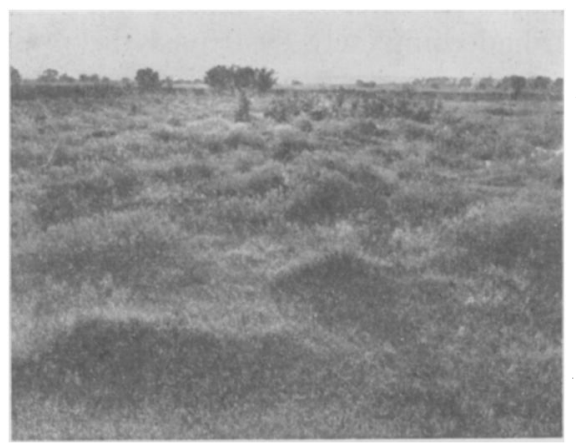

FIG. 11. Irregular grazing on creek bank where bluegrass had invaded in patches and a dense stand of little barley (Hordeum pusillum) grew between them. The winter annual was grazed to 2-3 inches, but most of the bluegrass was in flower at 22 inches in height. The steep creek bank in the background served as a fence. siderable lodging. Grazing was irregular but much more forage was obtained from the-upper half of the plants than during any previous year. With early maturity, consumption of this grass was reduced to about half that of June. This placed much greater grazing pressure on bluegrass which responded to the moist cool weather by making a good growth. Aside from the current new growth, much half-dried bluegrass was-removed from the roughs. The areas of closely grazed bluegrass wère rapidly and continuously expanded. Scarcity of other forage, with the disappearance of the prairie type, resulted in the removal of much bluegrass in July from places which in former years had remained almost ungrazed until September.

In August, selective grazing of the drying tops of wheat grass continued as in July, since despite very heavy grazing of bluegrass there was scarcely enough forage to satisfy the hungry livestock. Close grazing of relict prairie grasses was continued. Very close grazing of previously grazed bluegrass was maintained, since here the grass remained green all summer, although yield was decreasing. Hence the bulk of the bluegrass was obtained from the previously ungrazed places: Consumption of bluegrass reached its maximum for the season.

During the dry autumn the new shoots of wheat grass were never abundant and did not exceed 5-6 inches in height. Winter annuals were few and stunted and furnished almost no forage. The cattle were forced to eat the dry, bleached foliage of wheat grass in amounts similar to those in August, and above a height of 6-9 inches. Drought greatly reduced the yield of relict prairie grasses, which were consistently grazed to $0.5-1$ inch. Bluegrass everywhere was finally reduced to similar heights. Yield in the closely grazed type was small and consumption was mainly that of bluegrass in roughs with whatever grasses were intermixed (fig. 12). Tall dropseed was reduced to a lower stature (4 to 5 inches) than ever 


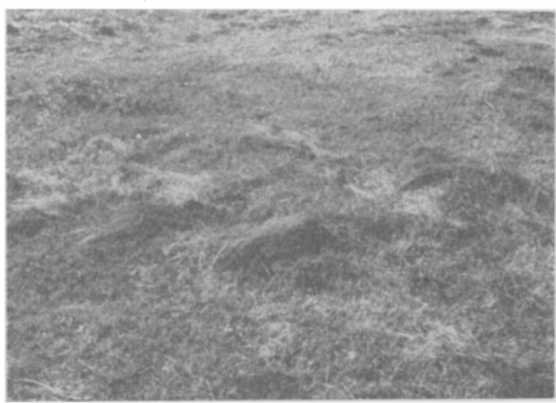

FIG. 12. A bluegrass rough almost reduced to a cleanly grazed area. The grass that was left here on October 1, '45, was all removed within two weeks to a height of 1-3 inches.

before. Slough grass and switchgrass were reduced to a height of 4 inches.

Bluegrass almost ceased growing in October. The upper parts of dried horseweeds were eaten where they had escaped grazing when green in the roughs. Bluegrass under the buckbrush had been grazed. Areas formerly dominated by slough grass and switchgrass with a dense understory of bluegrass, could scarcely be distinguished from the normal bluegrass sod. Vegetation over the whole pasture was reduced, except wheat grass, tall dropseed, and a few dense patches of horseweed and thistle, almost uniformly to a height of $0.5-2$ inches.

\section{Environment and grazing in ' 46}

Spring was nearly 3 weeks earlier than normal. Little precipitation had fallen during the winter but rainfall in March furnished sufficient moisture to promote rapid growth. The year was much drier than any of the preceding. Bluegrass became nearly dry by mid-June and grew poorly even when rains came. Drought recurred during the first half of July and throughout this month of high temperatures water content of soil and forage production were low. August was cool and moist except the last week which, like September, was dry. There was far less forage available than in '45. Forty-three head of yearling steers (an equivalent of 28 animal units) were placed in the pas- ture on April 9, 21 days earlier than the preceding year, and remained until October 20. Thus the total aninal months of grazing was 177 or 25 less than in ' 45 .

Bluegrass on manured soil and downy brome in bared places furnished practically all of the forage in April. Since bluegrass now covered most of the soil .on the creek bank and in formerly open places there was much less room for the winter annuals. Wheat grass, now 7-10 inches tall, was grazed only locally even where all debris had been cleared away the preceding year. Although the cattle ranged widely over the pasture in April it was not until early in May that grazing became rather general. Bluegrass in the dunged areas, which were grazed several times, no longer recovered rapidly. Elsewhere it grew slowly during the cool month of May. No grazing was evident in wheat grass.

By the middle of May much of the bluegrass had been removed to a height of 0.5 inch. A great loss of forage occurred when horseweeds almost failed to grow. Late in May, bluegrass was grazed uniformly and closely over the whole pasture and even in the patches. of buckbrush. Relict prairie plants, which appeared late, were very sparse. Irregular grazing of wheat grass began in mid-May, and by the end of the month it had been grazed far more than in any previous year. The stand was not so thick this drier season, nor were the plants of the

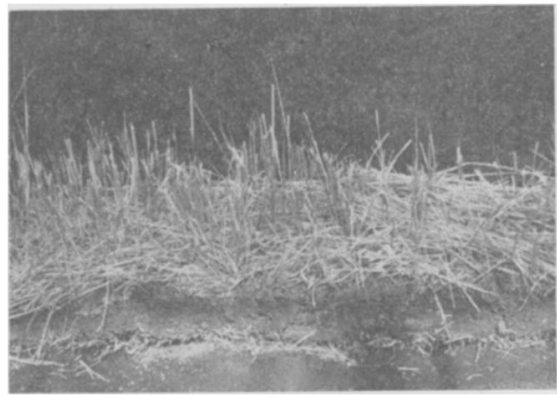

FIG. 13. Block of wheat grass sod showing heavy layer of debris mostly from previous season's growth and the relatively close grazing on May 30, '46. 
usual height. Some stands where the debris was lodged close to the soil were uniformly grazed to 2.5 inches, others remained undisturbed (fig. 13). Hairy chess (Bromus commutatus) was far less abundant and of smaller stature than in preceding years.

The first half of June was rainless. Bluegrass was grazéd uniformly and closely. It was two-thirds dry and there was practically no growth. Although bluegrass became green after heavy rains in mid-June, it grew but little. Hence, even close grazing resulted in low consumption of this grass. Wheat grass had been consumed in abundance, and it was much reduced in height even in places where last year's debris was plentiful. Grazing height varied from 1.5-5 inches. But since other forage was scarce the half-dried wheat grass was grazed in large amounts.

Not until mid-July was the drying vegetation revived by showers. But this relief was temporary and all through the month the available moisture supply was relatively low and temperatures were high (fig. 9). Grazing was close everywhere. Consumption depended almost entirely upon current growth. Bunches of tall dropseed were further reduced in height and the sparse horseweed was closely grazed. The hungry cattle ate the young flower heads of thistles as well as the bluegrass beneath the spiny plants. For the first time in the several years of pasturing, cattle found their way down the steep banks of the creek and climbed out into adjacent fields or jumped over the barbed wire fences in search of forage.

During a cool, moist August bluegrass grew fairly rapidly. Wheat grass revived and produced some new forage. Grazing was less general and not quite so close. Small amounts of unused forage accumulated.

Drought recurred in late August and September. Grasses almost ceased growing and despite very close grazing there was scarcely enough forage to maintain the cattle (fig. 14). After the first week

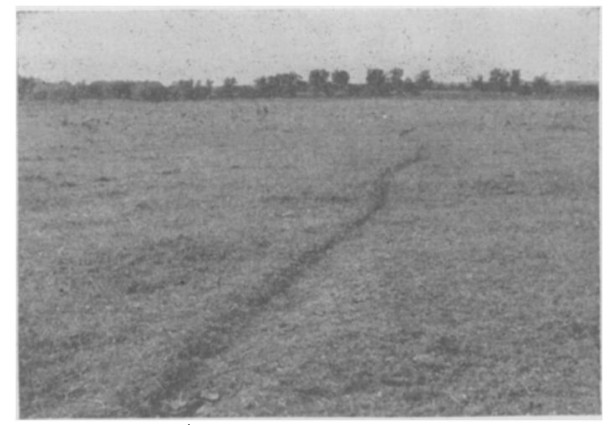

FIG. 14. View in the pasture in September, ' 46 , showing the uniformly close grazing. The path in the foreground extends through a patch of wheat grass, and beyond through bluegrass. Wheat grass was grazed to 2 inches and bluegrass to a height of an inch. .

in September grazing was again general. Bluegrass which had grown unmolested under buckbrush and ironweeds during August was sought and this supply of forage was rapidly depleted. The new crop of wheat grass was so sparse and short that it added almost nothing to the yield.

By October 1 the half-dry bluegrass was reduced in height to $1-0.5$ inch. Very little wheat grass exceeded 4 inches in height and much of it was only 2 inches. Forage was scarce. The cattle were hungry and apparently not gaining in weight. In the small, scattered patches of horseweed, the top half of the dry plants was removed and eaten. The scanty growth of winter annuals was grazed to within an inch of the soil. Rough pigweed, wild hemp, tumbleweed (Amaranthus graecizans), and indeed most weeds except thistles, prostrate spurges, and ironweed, had been almost entirely consumed. One could now view the short cover on this level land in any direction quite across the pasture. This general leveling of the wheat grass occurred this year for the first time. Tall dropseed had now been grazed mostly to 3-4 inches. Over large portions of the pasture it had practically disappeared. Growth was so slow that protected bluegrass reached a height of only 2-3 inches 
and relict big bluestem only 3-4 inches. The leafy twigs and fruits from the tops of buckbrush were eaten. The current yield of bluegrass and wheat grass was scarcely enough to maintain the cattle; they were restless and gaunt. No appreciable part of the available forage crop remained. It was clearly evident that supplementary feeding was imperative. Both hay and ground silage were placed in the pasture. The herd was removed to the feed lot on October 20, leaving the pasture greatly damaged.

\section{Early signs of degeneration}

Certain distinct signs of degeneration of prairie, resulting from grazing and the persistent spreading of bluegrass, were apparent by the end of ' 44 .

Invasion of bluegrass.-In May of '44, bluegrass dominated over only a third of the pasture. But a year later it had increased so rapidly and prairie grasses were so weakened under the heavy grazing imposed upon them that its territory had increased to three-fourths of the entire pasture. Bluegrass had spread over nearly all of the prairie in solid stands, and occupied numerous small but extensive patches formerly in weeds. It had reclaimed the 5 -acre subsere, and spread over the alluvial soil of the creek banks, and there had also been invasion into areas of wheat grass.

On the margins of the bluegrass patches, where they were in contact with open stands of wheat grass, grazing followed the route of the bluegrass rhizomes into the periphery of the wheat grass. Boundaries became less abrupt and not so distinct as previously. But where the wheat grass had lodged and the surface mulch was 2-4 inches thick, no invasion occurred. Invasion was also from various centers within the wheat grass alternes. In many places depth of dust was not sufficient to bury all the prairie grasses. These occurred as small islands or irregular strips between patches of wheat grass. The cattle grazed such places throughout the summer, first high or moderately but later more closely. In doing so considerable wheat grass in the area or on its margins was consumed. Bluegrass occurred in small amounts with the native grasses, and under continued grazing it gradually claimed the area and continuously enlarged it. Thus the adaptability of bluegrass to grazing as well as its persistence and aggressiveness was revealed.

Decreased vigor and waning of prairie grasses.-Big bluestem had been by far the most abundant prairie grass and the one that furnished the most and bestliked forage. Like little bluestem it is a warm-season grass and renews growth late in spring. Where bluestems had previously been grazed the plants became much more leafy at the base. When the foliage was removed it was quickly replaced, at least during the first half of the growing season. Little bluestem was well intermixed with big bluestem. Like many other bunch grasses in this prairie, it disappeared after only a few seasons of close grazing, such as occurred in the bluegrass type.

Where bluegrass was present it established a sod close to the bunches. Later, rhizomes grew through the crowns at a shallow depth (as they did also through the bunch or sod of big bluestem) and shoots of bluegrass appeared in the dead centers. Little bluestem, like most mid and tall grasses, is much more weakened than is bluegrass by close grazing. The sod-mat of bluegrass spread through the entire crown, and finally only a few leaves of little bluestem were found, if indeed all had not died. This also happened to most other heavily grazed bunch grasses and even to the sod-forming big bluestem and switchgrass. This story of invasion is told in figure 15 .

Even scattered stems of little bluestem were usually absent in formerly closely grazed areas of bluegrass. A weak growth of much depleted bunches or of fragments of bunches was found in some exclosures in more recently invaded areas. No thriving plants were seen; the scat- 

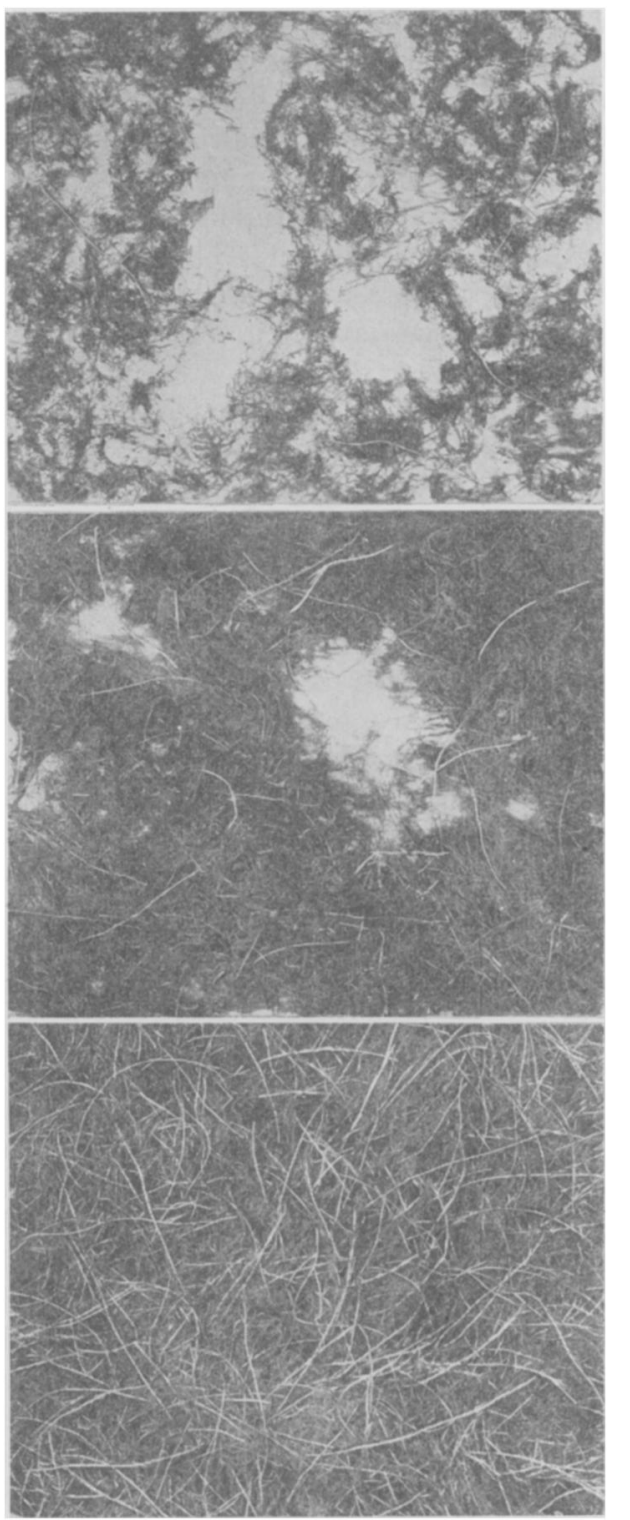

FIG. 15. Invasion of bluegrass into prairie sod. The web of roots and rhizomes occurred between a depth of 0.5 inch and 2 inches. The roots of all other vegetation were removed after the sod was cut at 2 inches in depth and the soil washed away. All are viewed from below. (Upper) Early invasion; the web became somewhat matted as, in washing, the roots sank to one plane. (Middle) Intermediate stage; the openings were occupied by needlegrass (Stipa spartea) and June grass (Koeleria cristata). Elsewhere the mat had spread through the sod of weakened big bluestem completely surround- tered relicts were all of low vigor. A wide distribution but small amounts of big bluestem now occurred. Even in former prairie most recently invaded by bluegrass, big bluestem composed only about a fifth of the monthly harvest in exclosures. Clearly it was about to disappear under the close grazing.

As a measure of the varying degrees of vigor of big bluestem, three sods each 6 inches long, 4 inches wide, and 2.5 inches deep were secured on May 17 . '45. One was from a greatly overgrazed area, the second, somewhat protected by bunches of tall dropseed, had been only moderately grazed, while the third, with full vigor, was from an adjacent prairie. The sods were planted in moist, sandy loam soil, each in a separate box $10 \times 10$ inches wide and 24 inches deep. Overgrazed plants, which were invaded by bluegrass, had stems which were only 11.5 inches tall. Those of the moderately grazed ones were $2-2.5$ inches high and more plentiful. The dense, vigorous stems of the control were 5-7 inches tall. These tops were apparently uninjured in transplanting. All bluegrass was removed at the beginning and whenever it reappeared. After 6 weeks the height of foliage was 10,16 , and 24 inches and the dry weight of tops $3.8,14.3$, and 35.3 grams, respectively. One side of each box was removed, the soil was washed from the glistening white new roots, and the plants were photographed (fig. 16). The number of roots was 39,71 , and 120 , in the preceding order. Their dry weight was $0.85,3.15$, and 10.66 grams, respectively. Thus, the weakened condition of overgrazed and even moderately grazed plants compared with ungrazed ones was shown. Plants of low vigor

ing its roots. Greatest vertical thickness of the mat is $3 / 16$ inch. (Lower) Uniform, dense, pure stand of bluegrass. Note great abundance of white rhizomes and dense masses of darkbrown roots. These formed a rug-like mat rather uniformly $1 / 3$ inch thick. Air-dry weights of the 16- by 18-inch mats above were 8.5, 37 . and 137 grams, respectively. 


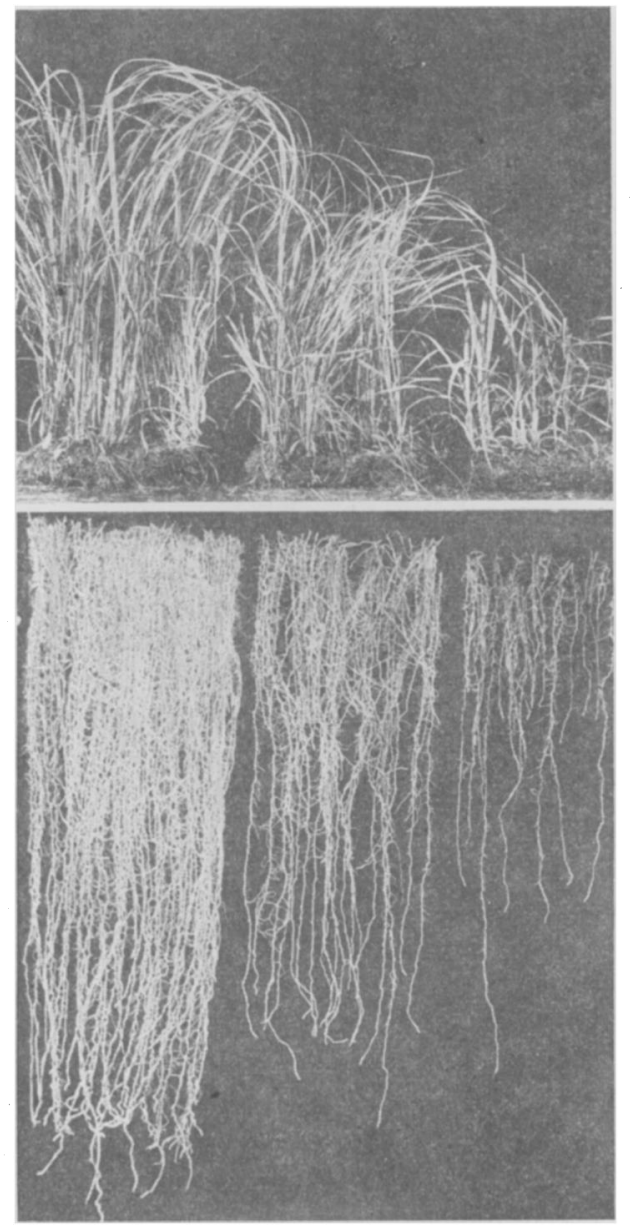

FIG. 16. Tops and new roots grown from blocks of sod of big bluestem during a period of 6 weeks. Plants on right had been overgrazed and were of low vigor. Those in the middle had been grazed moderately, and those on the left not at all.

cannot successfully compete with either bluegrass or weeds. Neither can they withstand drought; they are also subject to winter-killing (Biswell and Weaver, '33; Weaver and Darland, '47).

Tall dropseed was an abundant grass in this pasture. Its importance was due not to its grazing value, which is small, but rather to its effect in protecting other prairie grasses and thus creating roughs and hindering uniform grazing. Like needle grass and certain other species, tall dropseed became much more abundant during the dry cycle. It is a coarsestemmed bunch grass with leaves so tough that they are never eaten by preference. It did not occur in wheat grass except where it survived drought and dust burial, and was absent or nearly so in old, closely grazed bluegrass simply because it had finally been eaten. But elsewhere the bunches occurred thinly to thickly. Thus, it was the nucleus of many roughs and furnished refuge for. much palatable vegetation. Tall dropseed and wheat grass were the two great barriers to uniform grazing.

When tall dropseed was grazed, usually 10-14 inches of the base was left intact. Bunches were 9-13 inches wide across the leafy top after high grazing. Hidden between the bunches if aggregated or growing very close to them if isolated were big bluestem, needle grass, June grass, prairie dropseed, and other highly palatable grasses. By midsummer the cattle began to seek these out and graze them. At first such grazing was high, but once exposed they were grazed again and again; each time closer to the soil. Tops of the tall dropseed were also removed. Where this process had occurred the previous year and bunches of the tall dropseed were thus isolated, the new tops were invariably eaten and the grazing level was lowered.

Disappearance of roughs and bunches. -Roughs and ungrazed scattered bunches were a marked feature of the pasture in '42. Early in '43 the periphery of 10 representative roughs varying in size from 18 to 161 square feet and of irregular shape were staked, out in such a manner that their area could be redetermined. Four were in the bluegrass, 3 in prairie, and 3 in wheat grass (fig. 17). In early fall, 89 per cent of the area in bluegrass roughs was closely grazed, and close grazing extended almost throughout in late fall of '44. Grazing in roughs of relict prairie was similar. The first year 84 per cent of the 150 square feet was closely grazed and 87 per cent the second 


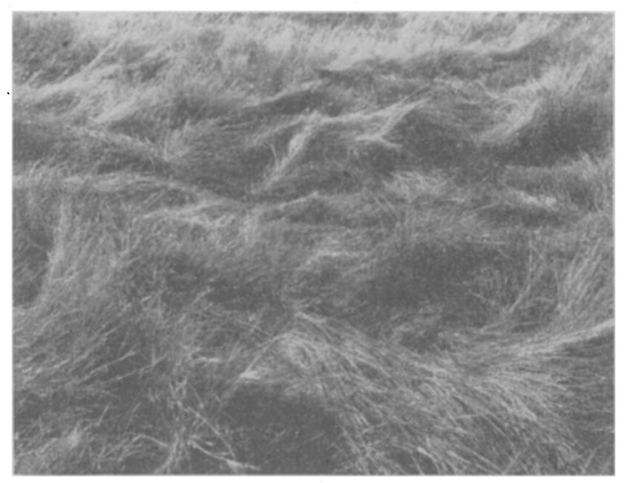

Fİ́. 17. Lodged and ungrazed bluegrass forming a rough on August 4, '45. Later in the season all of this grass was consumed.

year. Results in wheat grass roughs were very different. Of the three, totaling 314 square feet, only 3 per cent had been closely grazed late in '43. Otherwise they remained ungrazed. The next year only 8 per cent was closely grazed. From these data, which are in accord with extensive observations, it may be seen that under the conditions of grazing in this pasture roughs composed of palatable grasses disappeared quickly and almost completely. But where less palatable forage composed the rough, it remained essentially intact.

In order to determine whether or not new roughs were formed, an area of closely grazed pasture was selected and permanently marked out within a few feet of each of the preceding. These areas varied in size from 28 to 80 square feet. These experiments showed that where bluegrass or prairie grasses were once closely grazed such grazing was repeated, at least by fall. But where wheat grass was flattened in bedding grounds, grazed closely one year, or the old debris removed through clipping, there was no assurance that it would not revert into a rough after two or more years.

A large number of bunches of needle grass, big bluestem, little bluestem, prairie dropseed, and tall dropseed were definitely located and marked in the spring of ' 43 . Some had been ungrazed, some lightly or moderately grazed, and others had been eaten to the soil. When relocated and examined in the fall of ' 44,85 per cent had died or were so weakened that death seemed inevitable. Even casual examinas tion of the pasture revealed that the decrease in isolated bunches of all prairie grasses, except tall dropseed, had been very great.

Increase of weeds.-Another sign of degeneration was an increase in certain native forbs. Ironweed, formerly relatively few in numbers and local in distribution, had increased greatly. Often 8-13 stems occurred in a clump, and sometimes 45. Greatest gains were in closely grazed bluegrass. None occurred in wheat grass. It had spread thickly throughout the ravine, over its banks, and covered much territory elsewhere. Seedlings were common and widely distributed. A height of 4 feet was sometimes attained by old plants, with stems a half inch in diameter. When thick they hindered grazing, and when trampled down they also interfered with it. They distinctly characterize old pastures.

In ' 43 a single patch of thistle, Cirsium undulatum, occurred. By midsummer of '45 this native forb had spread widely. Five patches with 100 or more stems each were found, four with 25-50 stems, and a few plants had become established in each of 45 other places. Grass protected by the presence of this thistle is usually not grazed. Buckbrush was likewise extending its area into the bluegrass. Hoary. vervain (Verbena stricta), an introduced, inedible weed which becomes abundant in old pastures, was spreading widely.

New paths in late fall and deepening of the old ones indicated much trampling. In some places the cover of bluegrass had been thinned by too close grazing and trampling.

\section{Late signs of degeneration}

That the prairie grasses as a type had disappeared by the spring of ' 45 was clear, and that the pasture itself had greatly degenerated was indicated in many ways. 
Disappearance of relict grasses.-Individual species of prairie grasses were becoming rare; relict shoots of big bluestem persisted longest (fig. 18). With few exceptions, native prairie grasses were so weakened that their appearance in spring was much delayed. When they did appear they were often injured by trampling before they were tall enough to be grazed.

Penn sedge remained in the bluegrass sod for a long time because of its rhizomatous habit, but it had also greatly decreased and furnished little forage. Scribner's panic grass likewise was far less abundant in '46. Until the last year, needle grass had thrived; abundant seedlings appeared annually. This bunch grass, protected by dried stems produced the previous year, was usually not much grazed in spring because of the abundance of other forage. By fall the crop of coarse stems usually discouraged close grazing. It was estimated that needle grass had increased five-fold since ' 42 . But in the dry fall of ' 45 , due to scarcity of forage, the new foliage was so attractive that the old bunches were grazed closely and they were again grazed closely everywhere throughout the following summer. This phenomenon was confirmed by the fate of 50 marked and widely scattered bunches, all of which were kept grazed to 2 inches. Weaver and Hansen ('41) have shown that such close use of needle grass and prairie dropseed soon results in their death.

Slough grass and switchgrass had been removed by a much more gradual process of grazing and invasion by bluegrass. In ' 42 , only the panicles and higher leaves were eaten. In ' 43 , mostly denuded stems 2-3 feet high remained in fall. By the next year the tall grasses were so reduced and bluegrass had become so thick that a part of the area looked like a rough that had been grazed high. But many patches had been grazed closely. Finally in ' 46 these tall grasses had disappeared, at least above ground, and bluegrass had been so closely grazed that no part of the original

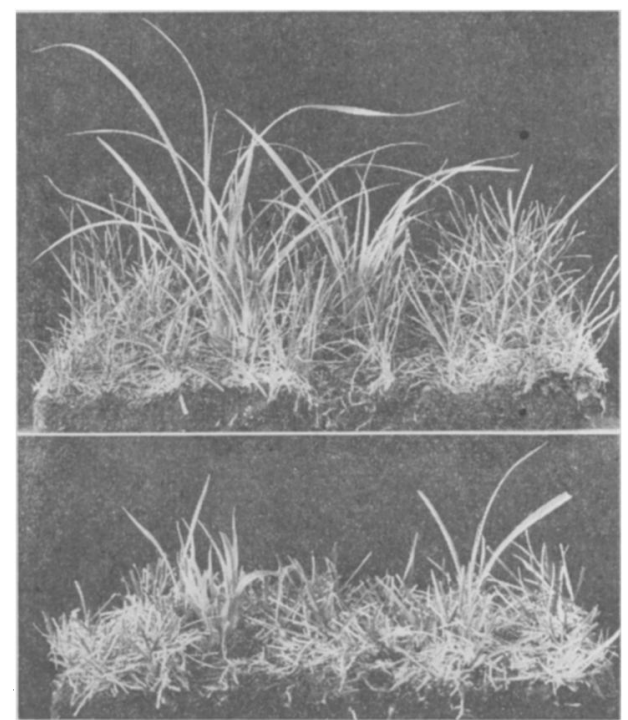

FIG. 18. (Upper) Detailed view of relict big bluestem growing in old bluegrass sod. This was taken on July 18 from an area exclosed to cattle on May 1, "46. Heights of grasses are about 7.5 and 3 inches. (Lower) Similar view of big bluestem in adjacent, unprotected bluegrass sod. The grass had been grazed to 1.5 inches. The bluestem grew more rapidly than bluegrass and is 3 inches high. The habit of producing foliage at a higher level than that of bluegrass but being grazed back to the same level as bluegrass is very disadvantageous to the bluestem.

tall-grass area could be distinguished from the rest of the pasture.

The extremely close grazing of wheat grass in ' 46 was detrimental and may result in decreased production for some time. Under proper management only about half of the yield is removed by the cattle (Crafts, '38).

Loss of native forbs. - The total list of prairie forbs was much greater in ' 45 than in ' 43 , since with the return of good rainfall many species reappeared as they did also in other prairies. Among these were Anemone cylindrica, Asclepias tuberosa, A. sullivantii, Astragalus crassicarpus, Delphinium virescens, Fragaria virginiana, Helianthus scaberrimus, Agoseris cuspidata, Specularia leptocarpa, Vicia americana, and others. Various 
legumes were also found, nearly all of which are valuable as forage. Forbs sometimes contribute 10-16 per cent of the total prairie yield (Weaver and Albertson, '43). They provide a valuable variety in the diet of livestock grazing native prairie. The loss of practically all prairie forbs occurred with the disappearance of the prairie and the thickening of the closely grazed bluegrass sod. This change was conspicuous.

Decrease in yield, closer grazing, and decrease in vigor.-The change in the plant population from that of prairie to bluegrass is in itself not only a sign of degeneration but also one of decreased forage production. Extensive experiments by Weaver and Hougen ('35) have shown that the production of bluegrass, although greater in early spring and late fall than that of prairie grasses, is much less during the summer. Thus, when prairie gives way to bluegrass the seasonal yield is often decreased 40 or more per cent. Not only had the highest yielding grasses been killed but also the type of vegetation with the most preferred, most varied, and best midsummer forage had disappeared.

Comparisons of the heights of grazing during each year, together with environment, indicate that the forage crop was steadily decreasing. Measurements were made in each control area at the end of each month; the averages are given in table I. Except in '46, previously grazed bluegrass was almost consistently grazed to a height of 1.5-3 inches until midsummer. After this it was grazed as closely as 0.5 inch. Grazing in the roughs varied between a height of $6-10$ inches during spring and summer but it was lower (3-5 inches) in fall. During the drier year of ' 46 after the highly productive prairie type had disappeared, even spring grazing averaged $0.5-1.5$ inches. This close usage continued all summer and was consistently 0.5 inch in autumn. Moreover, after midsummer, grasses in roughs were highly utilized, the stubble often being only $0.5-1$ inch high. Such close grazing and its accompanying tramp-
TABLE I. Average heights of grazing in inches of the several species of grasses each month

\begin{tabular}{|c|c|c|c|c|}
\hline Month & 1943 & 1944] & 1945 & 1946 \\
\hline & \multicolumn{4}{|c|}{ Bluegrass } \\
\hline \multirow[t]{3}{*}{$\begin{array}{l}\text { May } \\
\text { June } \\
\text { July } \\
\text { Aug. } \\
\text { Sept. }\end{array}$} & $\begin{array}{l}1.5-3.0 \\
1.5-3.0 \\
1.5-3.0 \\
0.5-1.5 \\
0.5-0.5\end{array}$ & $\begin{array}{l}1.5-2.5 \\
1.5-2.5 \\
1.5-2.5 \\
1.0-1.5 \\
0.5-1.5\end{array}$ & $\begin{array}{l}3.0-4.0 \\
2.5-3.0 \\
1.5-2.5 \\
0.5-1.5 \\
0.5-1.0\end{array}$ & $\begin{array}{l}0.5-1.5 \\
0.5-1.5 \\
0.5-1.0 \\
0.5-1.5 \\
0.5-0.5\end{array}$ \\
\hline & \multicolumn{4}{|c|}{ Big bluestem } \\
\hline & \multicolumn{2}{|c|}{ In prairie } & \multicolumn{2}{|c|}{ In bluegrass } \\
\hline \multirow[t]{3}{*}{$\begin{array}{l}\text { May } \\
\text { June } \\
\text { July } \\
\text { Aug. } \\
\text { Sept. }\end{array}$} & $\begin{array}{l}3-4 \\
3-10 \\
4-9 \\
3-4 \\
2-3\end{array}$ & $\begin{array}{c}2-9 \\
1.5-11 \\
1-8 \\
1-6 \\
0.5-5\end{array}$ & $\begin{array}{c}3-4 \\
2-3 \\
1-2 \\
0.5-0.5 \\
0.5-0.5\end{array}$ & $\begin{array}{l}0.5-1.5 \\
0.5-1.5 \\
0.5-1.0 \\
0.5-1.5 \\
0.5-1.0\end{array}$ \\
\hline & \multicolumn{4}{|c|}{ Little bluestem } \\
\hline & \multicolumn{2}{|c|}{ In prairie } & \multicolumn{2}{|c|}{ In bluegrass } \\
\hline \multirow[t]{2}{*}{$\begin{array}{l}\text { May } \\
\text { June } \\
\text { July } \\
\text { Aug. } \\
\text { Sept. }\end{array}$} & $\begin{array}{l}4-6 \\
4-6 \\
4-9 \\
2-4 \\
2-3\end{array}$ & $\begin{array}{l}2-12 \\
1-10 \\
0.5-7 \\
1.5-5 \\
0.5-5\end{array}$ & $\begin{array}{c}3-4 \\
2-3 \\
1-2 \\
0.5-0.5 \\
0.5-0.5\end{array}$ & $\begin{array}{l}0.5-1.5 \\
0.5-1.5 \\
0.5-1.0 \\
0.5-1.5 \\
0.5-1.0\end{array}$ \\
\hline & \multicolumn{4}{|c|}{ Wheat grass } \\
\hline $\begin{array}{l}\text { May } \\
\text { June } \\
\text { July } \\
\text { Aug. } \\
\text { Sept. }\end{array}$ & $\begin{array}{r}4-10 \\
10-12 \\
10-12 \\
10-12 \\
12-12\end{array}$ & $\begin{array}{r}6-16 \\
23-33 \\
24-38 \\
20-30 \\
15-20\end{array}$ & $\begin{array}{l}10-12 \\
12-24 \\
14-26 \\
10-26 \\
12-22\end{array}$ & $\begin{array}{l}7-10 \\
2.5-8 \\
1.5-5 \\
1.5-5 \\
1.5-4\end{array}$ \\
\hline
\end{tabular}

ling resulted in the opening of the cover and the entrance of many weeds.

Grazing heights of big bluestem in the prairie type were usually too low even in May, June, and July when growth was rapid (table I). They decreased consistently after July. The closest grazing occurred in fall. These conditions also maintained for little bluestem which, like big bluestem, was often removed to a height of only 0.5 inch in September of '44. Once the bluegrass became most abundant, the bluestems were grazed quite as closely as this dominant. This was 
rather consistently to $0.5-1.5$ inches after July, '45. Small wonder that the nutritious prairie grasses waned and died.

Removal of wheat grass was at a fairly high level, usually 6-12 or more inches, in May of each year. Nor was the average height further reduced later in the season (table I). The low preference for this species at first was the chief cause of overuse of prairie grasses and later that of bluegrass. Hence, close grazing of wheat grass in ' 46 was a most eloquent expression of the marked degeneration of the other portions of the pasture.

Further light upon decline of vigor may be had by comparing the average height of foliage produced under the several exclosures after a month's protection from grazing (table II). These data are on recovery of vegetation previously grazed. In '44, measurements of big bluestem are from the prairie type, thereafter they are from the invading bluegrass. type, where the relict big bluestem was grazed with bluegrass. Growth of bluegrass was usually much less in ' 46 than in preceding years. Since this occurred every month of the year, it can be attributed only partly to drought. Differences in big bluestem are even more marked. Recovery as expressed in height growth decreased consistently and greatly year by year during May, June, and July. It was also least in ' 46 during August and September.

TABLE II. Average height of foliage in inches under the several exclosures after one month's protection from grazing

\begin{tabular}{|c|c|c|c|c|c|}
\hline Year & May & June & July & Aug. & Sept. \\
\hline \multicolumn{6}{|c|}{ Bluegrass } \\
\hline $\begin{array}{l}1944 \\
1945 \\
1946\end{array}$ & $\begin{array}{l}3.0 \\
3.5 \\
3.0\end{array}$ & $\begin{array}{l}5.0 \\
3.5 \\
3.0\end{array}$ & $\begin{array}{l}4.5 \\
5.0 \\
2.5\end{array}$ & $\begin{array}{l}3.5 \\
3.5 \\
3.0\end{array}$ & $\begin{array}{l}3.0 \\
2.0 \\
1.5\end{array}$ \\
\hline \multicolumn{6}{|c|}{ Big bluestem } \\
\hline $\begin{array}{l}1944 \\
1945 \\
1946\end{array}$ & $\begin{array}{l}9.0 \\
7.0 \\
3.0\end{array}$ & $\begin{array}{r}15.0 \\
9.0 \\
5.0\end{array}$ & $\begin{array}{r}15.0 \\
9.0 \\
6.5\end{array}$ & $\begin{array}{l}8.0 \\
8.5 \\
6.0\end{array}$ & $\begin{array}{l}2.5 \\
3.0 \\
2.0\end{array}$ \\
\hline
\end{tabular}

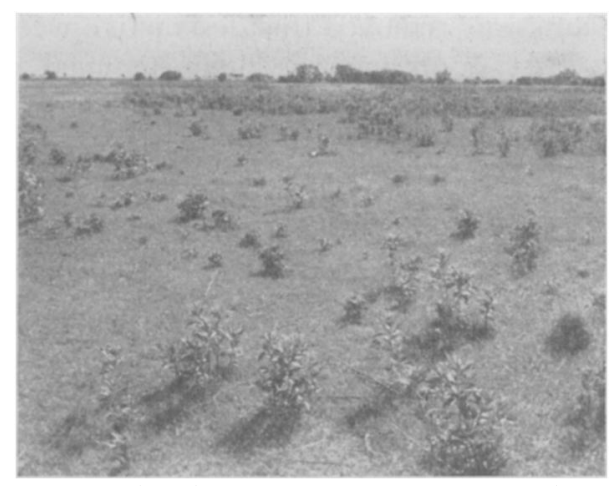

FIG. 19. Spreading of ironweed (Vernonia baldwinii), a native prairie forb, throughout the bluegrass pasture. These are mostly young plants which have grown from seed in the past 1-3 years. Photo. July 15, '46.

Invasion of weeds.-Close grazing of bluegrass had already decreased its density in the oldest bluegrass areas. The cover was thin in places and weeds, formerly excluded in prairie, found easy entry. In addition the spread of native weedy forbs and shrubs continued rapidly (fig. 19). The rhizomes of ironweed were approximately 3 inches deep and spread rapidly below the bluegrass sod. These coarse, much branched rhizomes and the tough, deeply penetrating roots are. shown in figure 20 . Once competition of the prairie

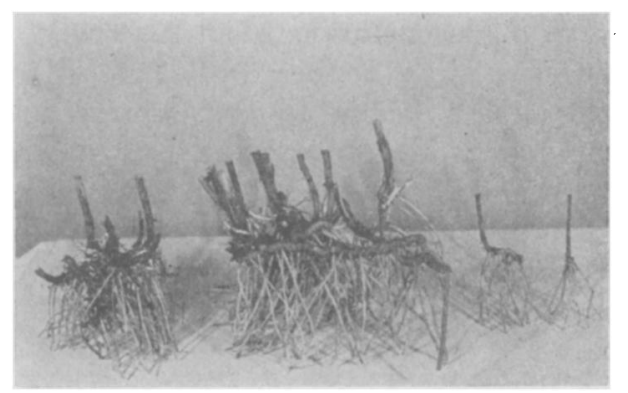

FIG. 20. Roots and rhizomes of ironweed. Plant on the right is one year old. It has 13 roots, no rhizome, but 6 buds to produce new stems. Excavated in March, '46. The next plant with 15 roots and 2 stems is 3 years old. An older plant with 6 stems and branched rhizomes is on the left. The largest plant, which probably was a seedling before the drought of ' 34 , has many stems and 153 roots'. Mature roots penetrate to depths of 10 to 12 feet. 
plants was removed this destructive weed, at first occurring as single-stemmed or very few-stemmed plants and only in the ravine, spread very widely over practically the entire pasture, except in wheat grass. In old pastures it often develops large bush-like clumps 1-3 feet in diameter from which even bluegrass is excluded.

Buckbrush had spread very rapidly since '44. Hoary vervain had become common; some old plants were very large. Other weedy species heretofore not found in the pasture are listed.

\section{Abutilon abutilon \\ Amaranthus blitoides \\ Amaranthus graecizans \\ Amaranthus retroflexus \\ Cirsium lanceolatum \\ Echinochloa crusgalli \\ Eragrostis cilianensis \\ Hordeum jubatum}

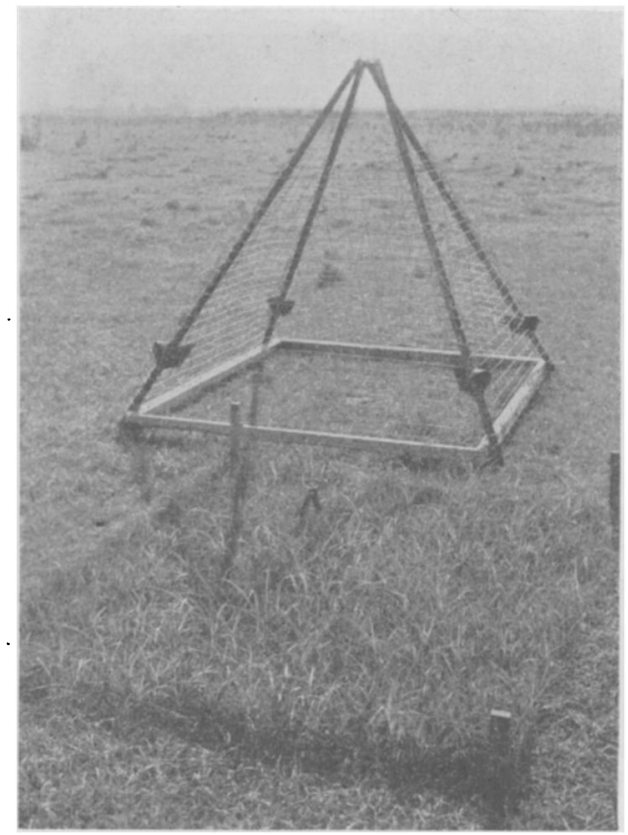

FIG. 21. A portable exclosure which had just been removed after protecting bluegrass during August, '46. This area of recently invaded prairie reveals some relict big bluestem. The grasses grew slowly during the dry summer and the monthly production was low.

especially its correlation with the changing plant population resulting from overuse of the pasture.

\section{Method of measuring consumption and yield}

Five or six widely separated sampling areas of about 10 square rods each were selected in each of the three grazing types. In each sampling area one 29square-foot exclosure, with its grazed control of similar size, was located in early spring. It was moved to a new location in this area at the end of each of the 5 or 6 months of the grazing season. During the first year, however, sampling was confined to the less weedy parts of the pasture where practically all of the grazing in the several types occurred.

In selecting the original location for an exclosure, two places were chosen 
TABLE III. A mount of new forage harvested from exclosure number 12 and from its control each month in '44. The air-dry weights are in grams

\begin{tabular}{l|r|r|r|r|r}
\hline \hline & May & June & July & Aug. & Sept. \\
\hline $\begin{array}{l}\text { Exclosure } \\
\text { Control }\end{array}$ & 962 & 1338 & 1494 & 1520 & 1782 \\
\hline Amt. consumed & 480 & 1245 & 1456 & 1423 & 1444 \\
\hline $\begin{array}{l}\text { Exclosure } \\
\begin{array}{l}\text { Control of pre- } \\
\text { ceding month }\end{array}\end{array}$ & 962 & 1338 & 1494 & 1520 & 1782 \\
\hline Amt. of yield & 962 & 856 & 249 & 64 & 359 \\
\hline
\end{tabular}

within 10-15 feet of each other in which the vegetation was as nearly alike as possible. In one the vegetation was to be clipped after a month of protection; the other, which was subjected to grazing, was also to be clipped at the same time. A coin was tossed to determine which of the two areas was to be protected. The exclosure was then set in place and stakes were driven into the soil in each corner to keep it from being pushed aside. Since the sides of the exclosure sloped inward from the base, it was not disturbed by the livestock. The control area was also clearly marked. At the end of each month at the time of the clipping, new places for the exclosure and control were selected in the same general area. These were as nearly as possible like the former control area and were selected before clipping, since both of the former plots were now to be clipped by hand close to the ground, closer than the cattle could graze. By subtracting the dry weight of vegetation of the control from that obtained from the exclosure, the monthly consumption from the 29square-foot area was obtained (fig. 21) (Fuelleman and Burlison, '39; Joint Committee, '43).

It was assumed that the average yield in any type during the first month was represented by the air-dry forage under that exclosure, since all debris from the previous year was carefully separated from the new vegetation and discarded. During the second month total yield was the amount that grew on the area newly exclosed less the amount of new vegetation remaining ungrazed in the control area of the preceding month. Clipping was uniform at all times, since one or the other of the writers was in direct charge each month (Klingman, Miles, and Mott, '43). An example of the results in ' 44 from an exclosure and controls in wheat grass is shown in table III. The average monthly consumption and yield as determined by the several exclosures are shown in graphs.

\section{Consumption in the wheat grass type}

The monthly consumption of wheat grass by years is shown in figure 22 . Trends of consumption for ' 43 and ' 44 are remarkably similar after June; increased consumption in autumn was evident both years. Consumption was greater in early spring of ' 44 because much more water was available for growth of the new crop. Smaller consumption in spring of ' 43 was directly correlated with a preceding dry fall and a very late spring, the highest monthly yield and highest consumption occurring in June instead of May.

Good winter precipitation and very heavy spring rainfall in ' 45 resulted in

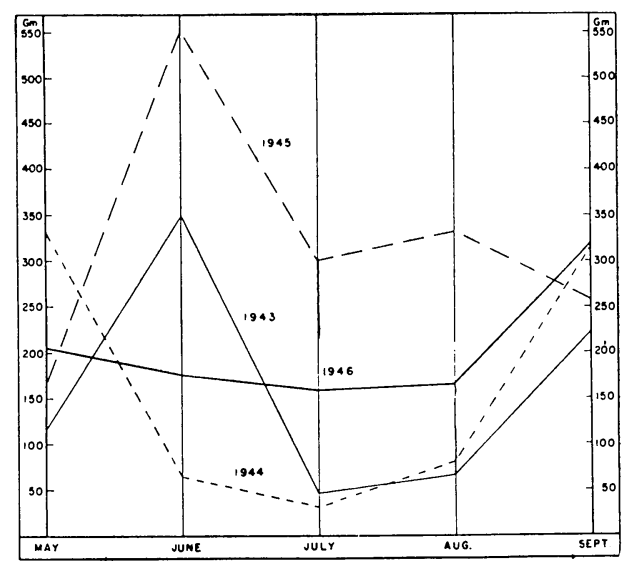

FIG. 22. Average amount of forage in grams consumed per unit area (29 square feet) in the wheat grass type each month of the grazing season of ' 43 , ' 44 , ' 45 and ' 46. 
by far the largest crop of wheat grass during the four years. Other forage was declining and consumption in this type was extremely high in June and continued high, compared with other years. There was no new development during the dry fall and consequently no increase in rate of consumption. Following this dry fall, '46 was a much drier year. But despite the lowest yield of any season, consumption, though relatively low in June, was steadily maintained until autumn when it was considerably increased, at the expense of the entire yield.

\section{Consumption in the bluegrass type}

Higher consumption of bluegrass in May the first year than in '44 and ' 45 was correlated with the low consumption of wheat grass (fig. 23). Otherwise the graphs of monthly consumption of bluegrass for the first three years are remarkably similar. Highest consumption in August and not July in ' 45 resulted in part from a maintained or even slightly increased yield during this relatively cool, moist month, but it was due partly to increased grazing pressure and lack of sufficient forage elsewhere. The graph for '46 is entirely different. Highest consumption in May clearly reflects the small amount of other more palatable forage. Decrease in June and September and also low consumption in midsummer reflected the drought only as it decreased yield. For after June all bluegrass was

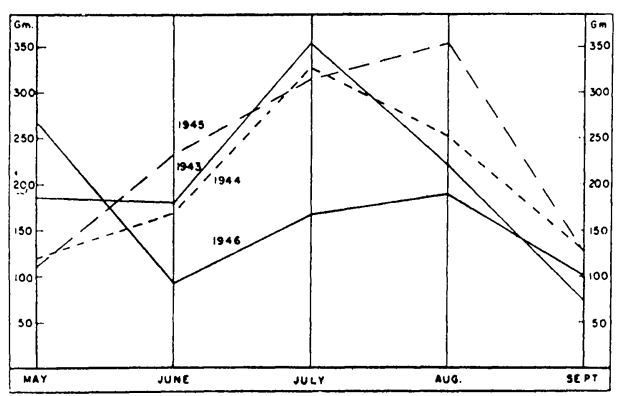

FIG. 23. Average amount of forage in grams consumed per unit area in the bluegrass type each month of the grazing season in '43, '44, '45 and ' 46.

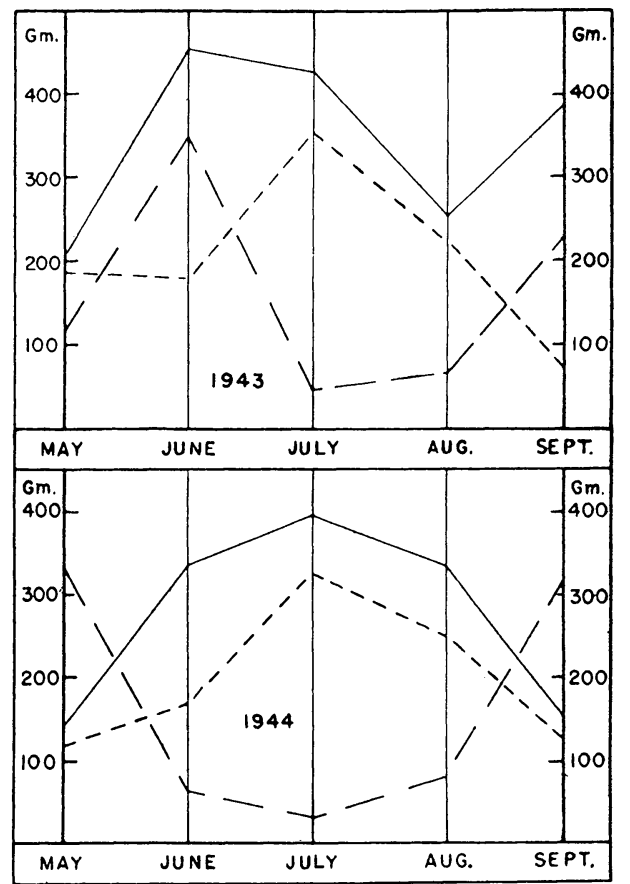

FIG. 24. Average amount of forage in grams consumed per unit area in the prairie type (continuous line), bluegrass type (short broken lines), and wheat grass type (long broken lines) in ' 43 and ' 44.

consumed almost as rapidly as it developed above the half-inch grazing level.

\section{Consumption in the prairie type}

The prairie type degenerated to bluegrass after two years, but an understanding of consumption here compared with that of other types is necessary to appreciate its loss. Moderate grazing in May increasing to heavy consumption in midsummer, as is shown in '44, is typical of this type (fig. 24). Except for drought, as in September, high consumption normally continued until the end of the grazing season. In August of '43, drought caused the cessation of growth of all grasses. Following rains and cooler weather in early fall, consumption again became high. The greater consumption of prairie grasses at all times than that of bluegrass is clearly revealed. The year ' 44 shows that consumption of prai- 
rie grasses was again higher throughout the summer than that of bluegrass. Wheat grass normally was consumed in considerable amounts only in spring and autumn. Undoubtedly relict prairie grasses in bluegrass promoted greater consumption during the first year ('45) after the invading bluegrass changed the prairie type.

\section{Patterns of Forage Production and Forage USE}

A comparison will first be made of monthly forage production year by year. Then the portion of the total yield which was consumed will be considered. This will throw much light not only on the causes for deterioration of excellent pasture to one of low grade but it will also clearly reveal the false economy of overuse. For in this pasture not only the interest (annual yield of forage) upon the investment (the prairie) was consumed but the capital investment itself was destroyed.

Yield of wheat grass during each of the 4 years is shown in figure 25. Differences in soil moisture and time of resumption of growth readily account for highest production in May, '44, and for maximum yields in June, ' 43 and ' 45. Considering that distribution of heavy rainfall in ' 45 was unusually favorable for wheat grass, the monthly yield and trend of the graphs are very similar until fall. Heavy rains and lower temperatures in ' 44 were unusually favorable for the growth of new shoots. But because of limited soil moisture, especially in spring (except in March) and autumn of '46, the graph showing production for that year is not only low but very different from those of preceding years.

Graphs of yield of bluegrass show similar trends in ' 44 and ' 45 (fig. 25). The somewhat higher yield in '45 resulted partly from the greater rainfall in May and June, but especially later from a considerable intermixture of big bluestem and other prairie grasses in the newer

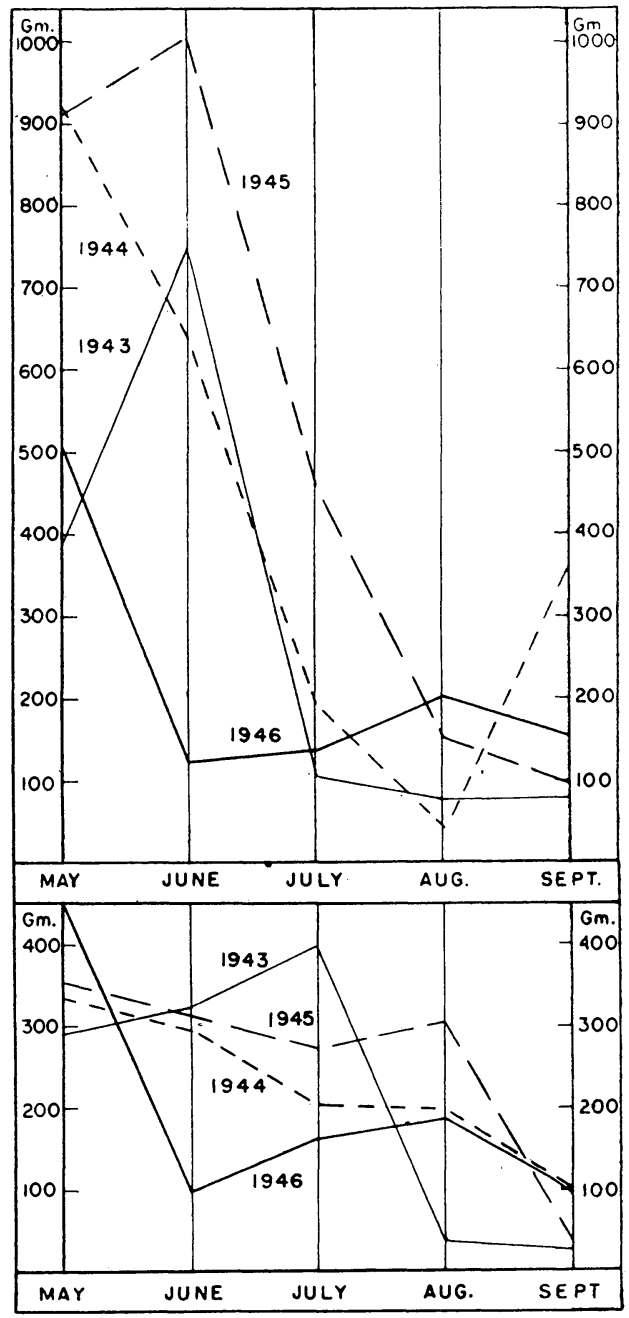

FIG. 25. (Upper) Average yield of forage in grams produced per unit area (29 square feet) in the wheat grass type each month of the grazing season in ' 43 to ' 46 inclusive. (Lower) Average yields in the bluegrass type.

bluegrass type. In certain extra exclosures which were not harvested until September, this amounted to a fifth of the total yield. Differences in the trend of the graph in ' 43 are closely correlated with favorable conditions of moisture and temperature for the development of bluegrass until July, after which there was prolonged drought and semidormancy. Maximum yield in June and July and little growth in fall are unusual. Early spring, 
and high rainfall in the spring of '46, resulted in a very high yield in May. The weakened grasses could not maintain high production during mild drought in June nor thereafter, since they were grazed far too frequently and too closely.

Relation of consumption to yield may be shown by means of graphs. In the prairie type, yield far exceeded consumption in May and June of both '43 and '44 (fig. 26). During the remainder of the season consumption was partly and often largely that of grass which had grown earlier. Causes of the decreased yield in the second year, which was more favorable to growth than ' 43 , were the very early grazing and the increased proportion of bluegrass intermixed with the prairie grasses as its invasion continued. Still another cause was the heavier grazing to which the prairie grasses were subjected in ' 44 and consequently the smaller chance for increased forage production. All of these factors are reflected in decreased seasonal yield, 2.62 tons per acre as against 3.54 tons the preceding year, a decrease of 26 per cent. Amount of forage consumed was reduced from 2.86 tons in ' 43 to 2.26 the last year of the prairie type, a reduc-

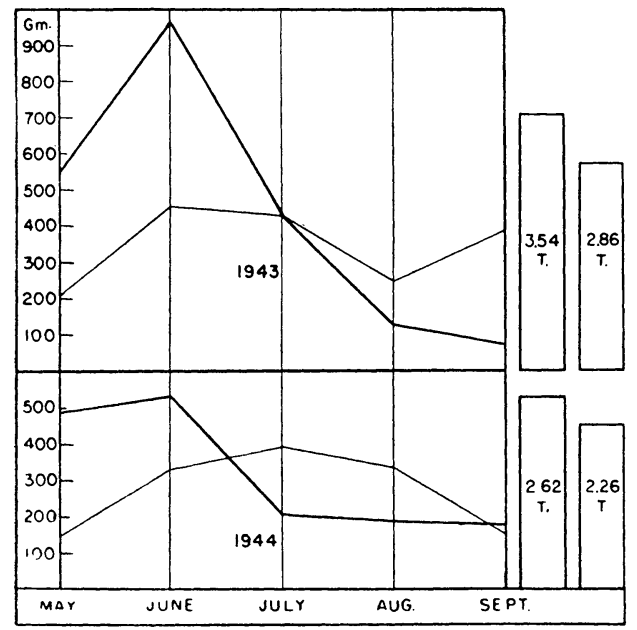

FIg. 26. Average yield (heavy lines) and average consumption (light lines) in grams per unit area in the prairie type each month of the grazing season of ' 43 and ' 44 . Seasonal yield and consumption are shown in tons per acre.

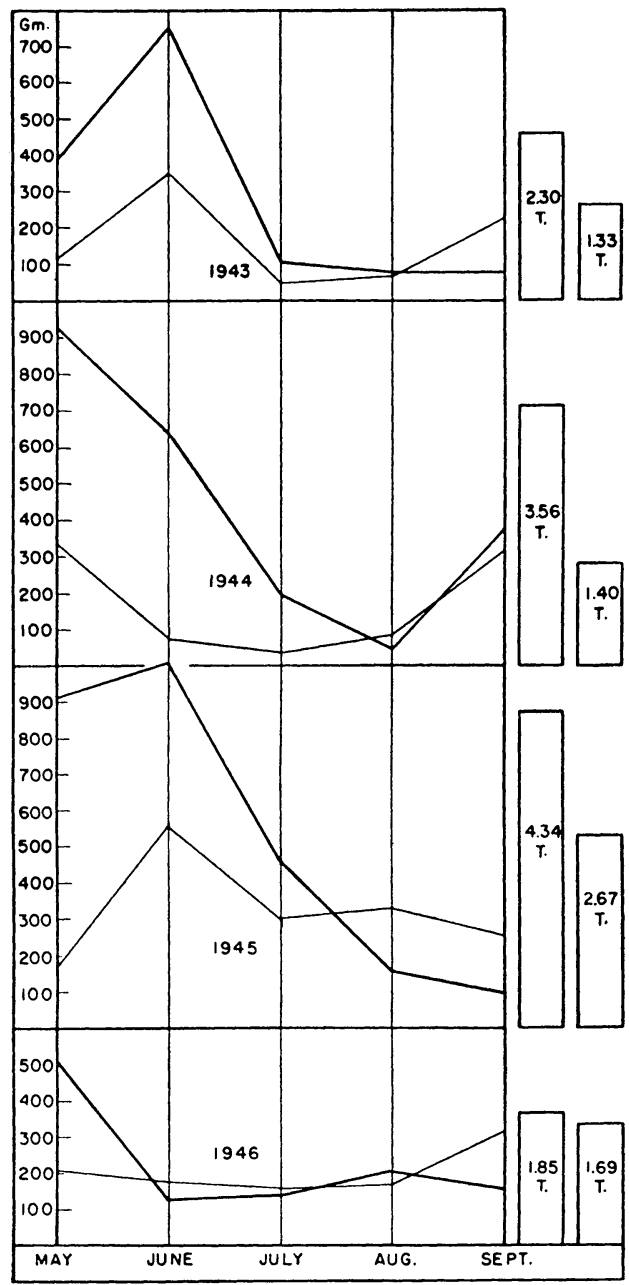

FIG. 27. Average yield (heavy lines) and average consumption (light lines) in grams per unit area in the wheat grass type each month of the grazing season of ' 43 , ' 44, , 45 and ' 46 . Seasonal yield and consumption are shown in tons per acre.

tion of 21 per cent. These data were obtained by adding the average monthly yields or consumption and calculating the amount per acre in tons.

The most striking features of the graphs of yield and consumption of wheat grass are the high yield and low consumption each spring and early summer (fig. 27). Differences in the trends of graphs have been explained. Consumption nearly always exceeded production in late summer 
and fall, unless environmental conditions were favorable for new growth, as in ' 44 . Yield and consumption were both greatest in '45. Yield was greatest (4.34 tons per acre) because of an unusually favorable environment; consumption was greatest because the disintegration of the prairie type had greatly reduced production of better-liked forage. The cattle were forced to consume more wheat grass, 2.67 tons per acre, that year. Even yield in spring was very low in '46. It remained so low that after late May consumption almost continuously exceeded production. Total yield was only 1.85 tons per acre or about 43 per cent of the yield of the preceding year. Despite the fact that all grass that had not been trampled down was consumed, the amount eaten was only 63 per cent as much (1.69 tons per acre) as the preceding year.

Graphs of bluegrass for the first three years are similar in that those of yield in May and June greatly exceeded those of consumption (fig. 28). Except in '43, when this condition continued through

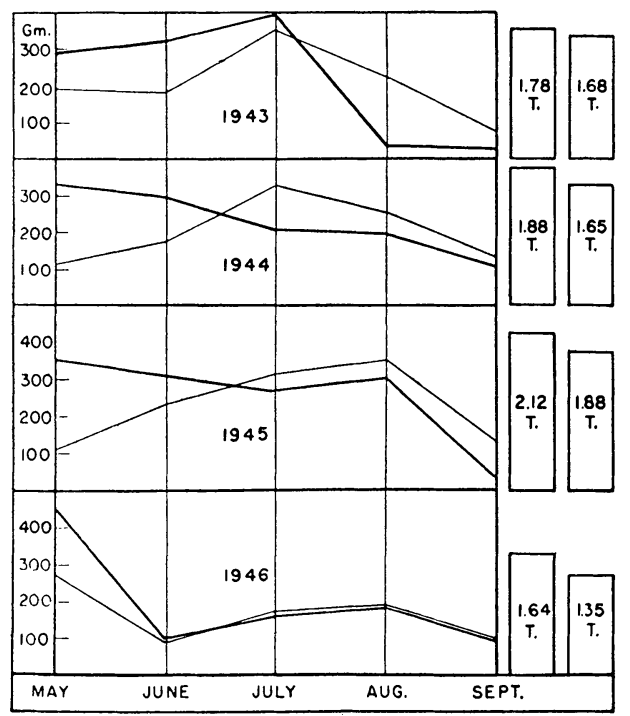

FIG. 28. Graphs showing average yield (heavy lines) and average consumption (light lines) in grams per unit area in the bluegrass type each month of the grazing season of '43, '44, ' 45 and '46. Seasonal yield and consumption are shown in tons per acre.
July, monthly consumption exceeded the monthly yield following June, a condition which was maintained into late fall. There was more bluegrass produced and more consumed during ' 45 than any other of the four years. The margin between consumption and yield of only about 11 per cent of the total was far too close for continued good yields of bluegrass. Except during early spring, yields in ' 46 were low. Consumption paralleled and slightly exceeded current yields during the entire summer.

\section{Discussion}

Comparison of the yearly grazing patterns reveals that in spring, annual grasses, mostly little barley, downy brome, and hairy chess, furnished much forage, the amount decreasing greatly in '46. Summer-cypress furnished considerable supplementary feed in August of '43 and during the whole summer of '44, after which it almost disappeared.

Wheat grass was grazed moderately in May, '43 and '45, but heavily in ' 44 and ' 46. Moderate grazing in May was followed by heavy consumption in June, and the heavy grazing in May, ' 44 , by low consumption until fall. In both ' 43 and ' 44 midsummer grazing was light, but it increased when the new crop developed in fall. But because of lack of much prairie grass in '45, grazing of wheat grass continued high in both July and August, decreasing with drought in September. In '46, because of a very limited supply of other forage, cattle ate wheat grass all summer until it was all grazed very closely in fall.

Prairie grasses furnished small amounts of forage in May of '43 and '44, both with a late spring. Much more prairie grass was consumed in June, July, and August than that of any other type. Consumption also remained greatest in prairie in September of ' 43 but declined greatly in ' 44 , owing to overuse of this type. It was replaced by bluegrass the next year, but scattered relicts increased the yield of bluegrass and its consumption as well. 
Bluegrass was grazed in May of the first two years only in patches where it had been closely grazed the preceding year. In ' 45 only fertilized areas where the grass grew rankly were grazed, but the grass in such places was consumed so rapidly during the early spring in ' 46 that grazing of this species became general. So plentiful was the forage in ' 43 that halfdried bluegrass was not removed from roughs until August, and then only partly the first year. But this occurred in June of ' 44 and ' 45 and was especially pronounced the third year. The last year forage was so scarce that the whole bluegrass type was grazed everywhere again and again; all edible plants in the entire pasture were consumed.

The grazing pattern varied because of the seasonal growth of the various components of the vegetation and as this was affected by early or late spring or by drought. But it also varied even more with change in the kind of vegetation available for consumption and the preference of the livestock. When prairie grasses were available in abundance, relatively less and largely only the young, previously grazed bluegrass was consumed. Wheat grass was grazed only when green and most succulent; dried plants were largely avoided. When the prairie grasses were replaced by the much lower-yielding bluegrass in '45, there was not enough fresh bluegrass to supply the demand. Halfdried maturing plants were consumed, beginning early in the season, and wheat grass was consumed in larger amounts than in any previous year. The grazing pattern had changed remarkably. A still different pattern prevailed in '46, since there was little preference and indeed not enough forage. Both bluegrass and wheat grass whether green or dry were consumed wherever they were found.

That the cattle consumed only 58,39 , and 61 per cent of the crop of wheat grass in the first three years, respectively, but 81 and 86 per cent of the forage in the prairie type, as long as it endured, was clear evidence of their preference for prairie grasses. Only in '46 when other forage was scarce was consumption in wheat grass high, reaching 91 per cent. This was far too great a utilization for the maintenance of wheat grass (Crafts, '38). Only about 6 per cent of bluegrass remained in closely grazed places in ' 43 . All but about 12 per cent of the entire crop was consumed each of the next two years, and in ' 46 the short foliage of bluegrass was grazed very closely everywhere.

The history of pasture utilization in the mid-west has been one of exploitation followed by depletion of the vegetation. Prior to '00, for example, most of the pastures in the great bluestem areas of east-central Kansas were stocked at the rate of 2 acres per animal unit. This rate was gradually decreased until just before the great drought the best pastures were carrying one animal to 4 acres. During later years the average grazing capacity was 5-7 acres per mature steer each year (Aldous, '38). Clearly the stocking rate in this study of 1.7 acres per animal unit per year, although not unusual where little attention is given to pasture management, was far too high.

Early spring grazing of the prairie grasses before the plants are 4-5 inches high is very injurious (Anderson, '40). Hence, continuous grazing after the new crop of winter annuals and wheat grass was abundant in early spring was especially harmful to the warm-season prairie grasses. They were eaten as they appeared or were trampled into the wet soil. Early and heavy grazing of wheat grass followed by grazing in other pastures of brome grass or winter rye until the prairie grasses had reached a condition of "range readiness" would have preserved this valuable forage type (Weaver and Hougen, '39). Protecting a pasture the first 4-6 weeks of the growing season, a common practice in well managed bluestem pastures, is distinctly favorable to wheat grass where it has invaded the bluestem pastures during the great drought.

Most farmers and even many cattle growers do not realize what experience 
has repeatedly shown, that with proper rates of stocking, pastures and ranges will produce greater profits even for the current year than the heavier rates of stocking too often practiced (Costello, '44). Maximum number of animals, which is a usual cause of pasture degeneration, is not necessary to produce either maximum gains in beef or higher profits (Allred, 40).

\section{SUMMARY}

Large areas of lowland prairie in Iowa, Nebraska, and adjacent midwestern states have degenerated into weedy bluegrass or buffalo grass pastures of low productivity, the true-prairie grasses disappearing as a result of long overuse.

Changes in the vegetation and decreased production of forage have been studied in a typical tract of low, level, fertile prairie at Lincoln, Nebraska, over a period of four years. Frequent examination of the species that were being grazed was made and especially the degree to which they were grazed and their response to grazing injury were observed. This was supplemented by means of numerous, large, portable exclosures which protected selected areas from disturbance each month, thus furnishing an excellent criterion of the rate of growth in the prairie and, by clipping, the quantity of forage consumed.

The three types or communities of grass were (1) western wheat grass (Agropyron smithii), which had invaded the native prairie during drought and formed extensive pure stands totaling a third of the entire 50-acre tract, (2) Kentucky bluegrass (Poa pratensis) of similar extent, which resulted from previous grazing, and (3) native prairie, mostly of big bluestem (Andropogon furcatus) but including other tall, coarse grasses and some little bluestem ( $A$. scoparius) and others of mid-grass stature.

The pasture was heavily stocked each year with about 45 head of year-old steers. Grazing began about May 1 and extended well into October, hence there were ap- proximately 200 animal months of grazing. Both precipitation and temperature were so favorable to growth during ' 43 , ' 44 , and '45 that even bluegrass remained green and continued growing almost all summer. But in ' 46 the herd was reduced considerably. This was a drier summer and the plant cover had degenerated greatly.

The seasonal pattern of grazing varied mostly with the type of vegetation available to the stock and its period of development and consequent varying palatability. It also varied with the grazing pressure, which increased gradually until ' 46 when, partly due to dry weather, it became very great.

During the first two years little barley (Hordeum pusillum), downy brome (Bromus tectorum), and hairy chess ( $B$. commutatus) growing in small, droughtformed, bared places furnished much forage in spring, but they were later mostly replaced by bluegrass.

Wheat grass was grazed only moderately in May of '43 and '45, years with a late spring, but heavily, as in June, until it matured. In '44, heaviest grazing occurred in May, with a great decrease in June. Midsummer grazing was light to almost nil the first two years when much prairie forage was available but increased in fall with the production of new shoots. But in '45, when the prairie grasses were greatly reduced, much wheat grass was eaten during both summer and fall. The entire crop was gradually consumed for the first time in ' 46 .

Each year grazing shifted to prairie grasses as soon as they were a few inches tall, usually in mid-May, and they were repeatedly and heavily grazed until late fall. This overuse destroyed the type by '45; only weakened remnants of prairie grasses remained in the invading bluegrass sod. Their loss imposed much closer grazing on the lower yielding bluegrass.

With decrease in annual grasses, grazing of bluegrass began earlier. At first in ' 45 and ' 46 only fertilized spots where 
the grass grew rankly were grazed; then areas previously grazed were regrazed repeatedly. Each year general grazing of bluegrass became earlier, and in ' 46 it occurred in May, after which all remaining forage was consumed as rapidly as it was produced.

Numerous signs of degeneration of the vegetation were apparent in ' 44 . Chief among these were the steady invasion of prairie by bluegrass, decreased vigor and waning of prairie grasses, and the disappearance of forage in numerous formerly ungrazed patches and of isolated old bunches as well. Certain inedible prairie forbs increased greatly and bared spots became populated with various introduced weeds. Several of these phenomena were measured quantitatively.

By '46 prairie grasses became rare; relict shoots of big bluestem persisted longest. Loss of practically all prairie forbs occurred with the disappearance of the prairie type. Extremely close grazing of wheat grass in ' 46 was detrimental to this species.

The change from prairie to bluegrass was a sign both of degeneration and decreased forage production. The yearly decrease in height of grazing indicated that the vegetation was steadily weakening. Bluegrass during ' 43 to ' 45 was almost consistently grazed to only $1.5-3$ inches until midsummer, but thereafter as closely as 0.5 inch. But in ' 46 even in spring grazing was $0.5-1.5$ inches, and by midsummer all bluegrass was very closely grazed. Likewise, height-growth in exclosures was much reduced.

In the weakened and less dense bluegrass sod native weedy forbs and shrubs spread rapidly and many weeds found only in old pastures became established. This foreshadowed the final weed stage in degeneration.

Monthly consumption of forage was ascertained in 5 or 6 sampling areas in each type. This was accomplished by clipping the forage close to the soil at the end of each month in the 29-squarefoot exclosures and in adjacent grazed areas of similar size. The air-dry weight of the first lot of forage minus that which was uneaten in the adjacent area equalled the amount consumed. New locations were used each month.

Monthly consumption of each type of forage was compared year by year. It was highest in prairie until the type disappeared, intermediate in bluegrass, and least (except in spring and fall) in wheat grass.

Yield was ascertained each month by subtracting from the dry-weight of the forage in an exclosure at the end of the month the dry-weight of the approximate amount that occurred there at the beginning of the month. Total yield of wheat grass was highest each year except the first and that of bluegrass least. Yields in each type were compared year by year, all being greatly reduced by ' 46 .

A comparison was made of monthly yields and monthly consumption in each type year by year. Yield of all grasses usually greatly exceeded current consumption until midsummer. Thereafter the livestock also ate forage produced earlier and consumption usually exceeded current growth or yield. But in ' 46 degeneration had proceeded so far that in this drier season, after May, yield and consumption were practically identical.

Only 39 to 61 per cent of the very high yields of wheat grass (2.3 to 4.3 tons per acre) was consumed until ' 46 when forage was so scarce that 91 per cent of the crop was eaten. But even when forage was plentiful in ' 43 and ' 44,81 to 86 per cent of the prairie yield (3.5 and 2.6 tons per acre) was consumed. All but 6 to 12 per cent of the yield of 1.8 to 2.1 tons of bluegrass was eaten by October of each of the first three years. With the small yield of 1.6 tons in '46, even portions of thistles, dry wheat grass stubble, and twigs of buckbrush were consumed in addition to all the bluegrass. 


\section{Literature Cited}

Aldous, A. E. 1938. Management of Kansas bluestem pastures. Jour. Amer. Soc. Agron. 30: 244-253.

Allred, B. W. 1940. Range conservation practices for the Great Plains. Misc. Pub. No. 410, U. S. D. A., Washington, D. C.

Anderson, K. L. 1940. Deferred grazing of bluestem pastures. Bull. 291, Kan. Agric. Expt. Sta.

Biswell, H. H., and J. E. Weaver. 1933. Effect of frequent clipping on the development of roots and tops of grasses in prairie sod. Ecology 14: 368-390.

Costello, D. F. 1944. Efficient cattle production on Colorado ranges. Bull. 383-A, Colo. State College Ext. Serv.

Crafts, E. C. 1938. Tentative range utilization standards. Research Note 44, Southwestern Forest Range Expt. Sta.

Fuelleman, R. F., and W. L. Burlison. 1939. Pasture yields and consumption under grazing conditions. Jour. Amer. Soc. Agron. 31: 399-412.

Joint Committee of Am. Soc. of Agron., Am. Dairy Sc. Assoc., and Am. Soc. of Animal Production. 1943. Preliminary report on pasture investigations technique. Jour. Dairy Sci. 26: 353-369.

Klingman, D. L., S. R. Miles, and G. $O$. Mott. 1943. The cage method for determining consumption and yield of pasture herbage. Jour. Amer. Soc. Agron. 35: 739-746.

Weaver, J. E., and F. W. Albertson. 1943. Resurvey of grasses, forbs, and underground plant parts at the end of the great drought. Ecological Monogr. 13: 63-117.

Weaver, J. E., and R. W. Darland. 1947. A method of measuring vigor in range grasses. Ecology 28: 146-162.

Weaver, J. E., and T. J. Fitzpatrick. 1934. The prairie. Ecological Monogr. 4: 109295.

Weaver, J. E., and W. W. Hansen. 1941. Native midwestern pastures; their origin, composition, and degeneration. Bull. 22, Univ. Neb. Cons. and Surv. Div.

Weaver, J. E., and W. W. Hansen. 1941a. Regeneration of native mid-western pastures under protection. Bull. 23, Univ. Neb. Cons. and Surv. Div.

Weaver, J. E., and V. H. Hougen. 1939. Effect of frequent clipping on plant production in prairie and pasture. Amer. Midl. Nat. 21: 396-414. 